\title{
FONTES DE INFORMAÇÃO EM TURISMO
}

JAKELINE VILELA DE PÁDUA

Orientadora: Profa . Ellen F. Woortmann

Brasília - 2006 


\section{FONTES DE INFORMAÇÃO EM TURISMO}

\section{JAKELINE VILELA DE PÁDUA}

Orientadora: Profa. Ellen F. Woortmann

Monografia apresentada ao Centro de Excelência em Turismo - CET, da Universidade de Brasília - UnB, como requisito parcial à obtenção do grau de Especialista em Formação de Professores e Pesquisadores em Turismo e Hospitalidade. 
UNIVERSIDADE DE BRASÍLIA

Centro de Excelência em Turismo

Monografia apresentada ao Centro de Excelência em Turismo - CET, da Universidade de Brasília - UnB, como requisito parcial à obtenção do grau de Especialista em Formação de Professores e Pesquisadores em Turismo e Hospitalidade.

\title{
JAKELINE VILELA DE PÁDUA
}

Aprovado por:

\author{
Profa. Ellen F. Woortmann \\ Orientadora
}

Professor: .....

Professor: .....

Brasília, 10 de fevereiro de 2006. 
A Aisha, minha vida... 


\section{AGRADECIMENTOS}

Agradeço em especial a Núbia Macedo pelo apoio e incentivo na realização deste curso.

A professora Ellen Woortmann, que acreditou na idéia permitindo total liberdade de ação e criação.

A minha família, em especial ao meu pai, pelo apoio integral e incondicional, inclusive no incentivo deste trabalho.

A Mariela, pela paciência, atenção e disposição.

Aos verdadeiros amigos, estes sabem quem são, pelo carinho, compreensão e contribuição em todos os momentos. 
"Viver de fato é viver com informação". (NOBERT WIENER) 


\section{RESUMO}

As sociedades contemporâneas dispõem e utilizam, em formatos diversos, novas tecnologias de informação e comunicação (TIC's), configurando a chamada Sociedade da Informação. O volume sempre crescente de informações geradas pela comunidade científica e a forma como se acumulam, trazem complicações no processo de comunicação e recuperação destas informações pelos pesquisadores, que se queixam da quantidade de informações dispersas entre as várias fontes e canais de informação. Este estudo discute como as práticas de pesquisa científica são afetadas pelas novas tecnologias. Descreve estratégias de busca na área de Turismo e sugere orientações no processo de recuperação da informação especializada. Apresenta indicações de acessos online a bibliotecas virtuais e bases de dados com enfoques interdisciplinares na área de Turismo, com o intuito de melhorar a qualidade e a eficiência dos serviços relacionados com a identificação, seleção e provimentos de informação.

Palavras-chave: Informação Especializada; Tecnologia da Informação e Comunicação; Fontes de Informação Eletrônica; Estratégia de Busca; Base de Dados; Pesquisa em Turismo. 


\begin{abstract}
The societies contemporaries make use and use, in diverse formats, new technologies of information and communication (TIC's), configuring the call Society of the Information. The increasing volume of information always generated for the scientific community and the form as if accumulates, brings complications in the process of communication and recovery of these information for the researchers, who if complain of the amount of dispersed information between the some sources and information channels. This study it argues as the practical ones of scientific research are affected by the new technologies. It describes strategies of search in the area of Tourism and suggests guide lines in the process of recovery of the specialized information. Online presents indications of accesses the virtual libraries and databases with approaches interdisciplinares in the area of Tourism, with intention to improve the quality and the efficiency of the services related with the identification, selection and supply of information.
\end{abstract}

Key-words: Specialized Information; Technology of the Information and Communication; Sources of Electronic Information; Strategy of Search; Database; Research of Tourism. 


\section{LISTA DE FIGURAS}

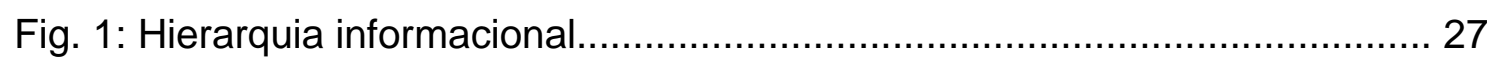

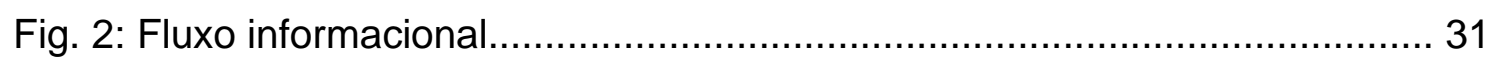

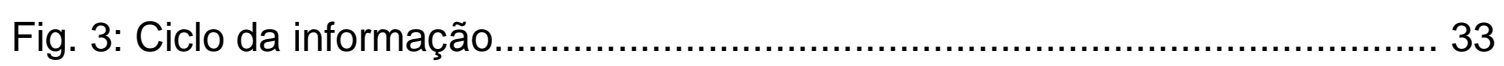

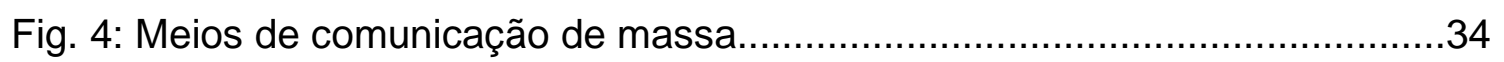

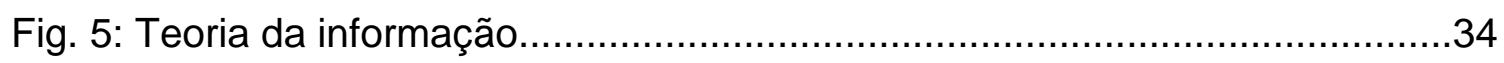

Fig. 6: A multidisciplinaridade da pesquisa em Turismo.................................57 


\section{LISTA DE ABREVIATURAS}

BDTD: Biblioteca Digital de Teses e Dissertações

BVS: Biblioteca Virtual de Saúde

CAPES: Coordenação de Aperfeiçoamento de Pessoal de Nível Superior

C\&T: Ciência e Tecnologia

CCN: Catálogo Coletivo Nacional de Publicações Seriadas

CCT: Conselho Nacional de Ciência e Tecnologia

CD-ROM: Compact Disc Read Only Memory

CNPq: Conselho Nacional de Desenvolvimento Científico e Tecnológico

COMUT: Programa de Comutação Bibliográfica

DSI: Disseminação Seletiva da Informação

ERIC: Educational Resources Information Center

FTP: File Transfer Protocol

IBICT: Instituto Brasileiro de Informação em Ciência e Tecnologia

ICT: Informação Científica e Tecnológica

LILACS: Literatura Latino-Americana e do Caribe em Ciências da Saúde

NDLTD: Networked Digital Library of Theses and Dissertations

OCLC: Online Computer Library Center

OPAC: Online Public Acess Catalog

OSI: Open Systems Interconnection

SciELO: Scientific Eletronic Library Online

TCP/IP: Transmission Control Protocolo / Internet Protocol 
TIC's: Tecnologias de Informação e Comunicação

UNESCO: Organização das Nações Unidas pela Educação, Ciência e Cultura Unesp: Universidade Estadual Paulista

Unisist: Universal System for Information in Science and Techonology

URL: Uniform Resource Locator

USP: Universidade de São Paulo

WWW: World Wide Web 


\section{SUMÁRIO}

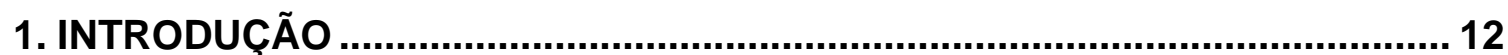

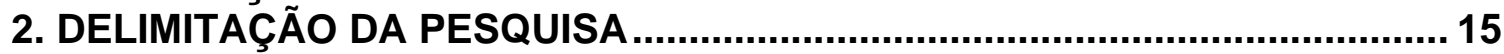

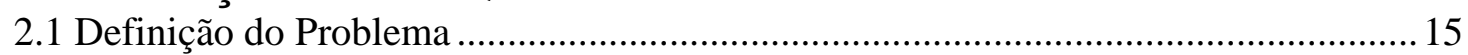

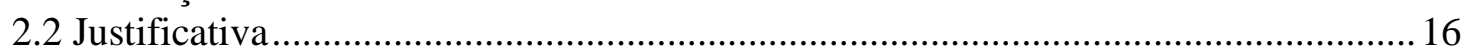

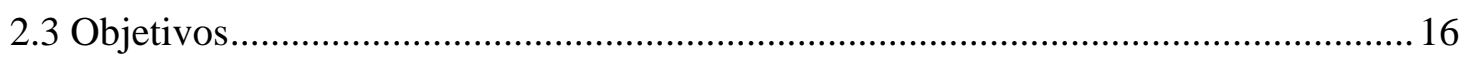

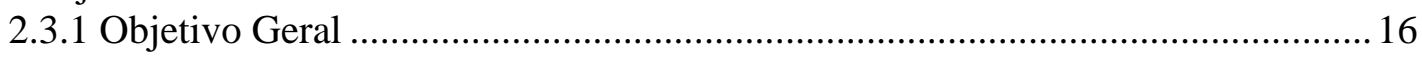

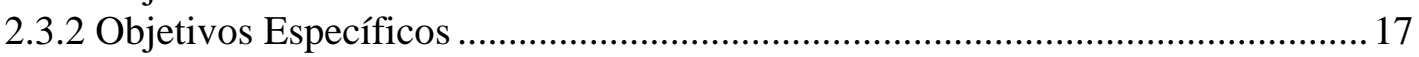

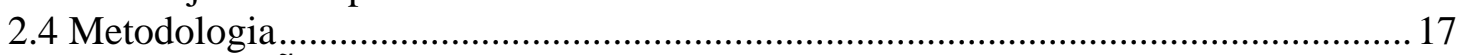

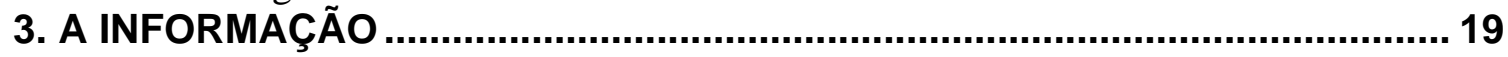

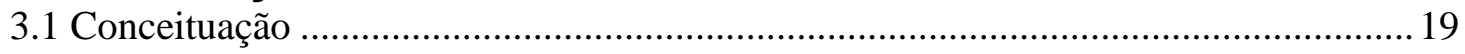

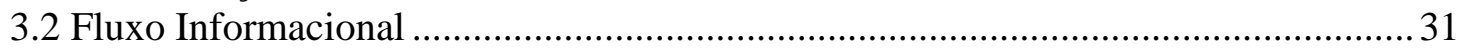

3.2.1 O Processo de Comunicação da Informação ...................................................... 32

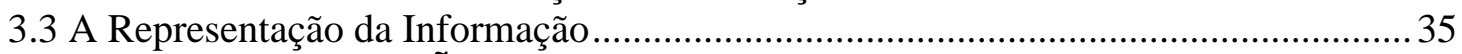

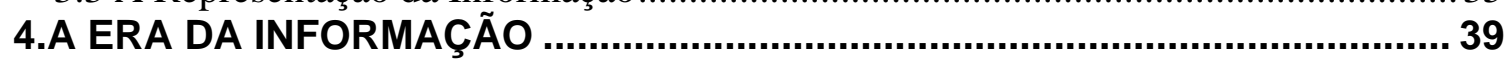

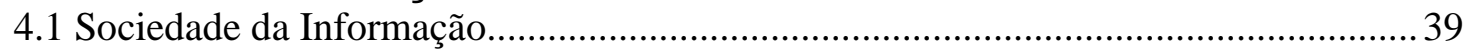

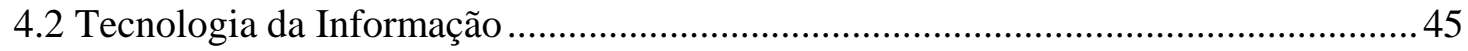

5. METODOLOGIA DA PESQUISA EM TURISMO ........................................... 51

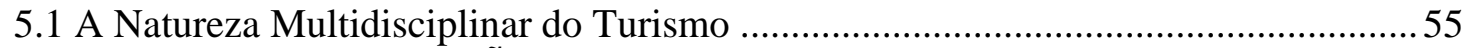

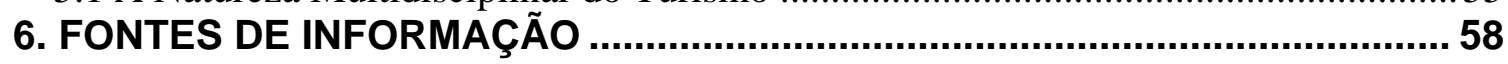

6.1. Evolução dos Suportes de Informação ......................................................................5

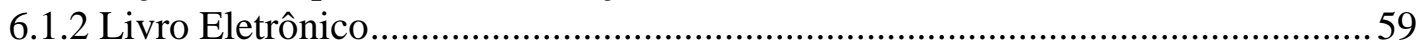

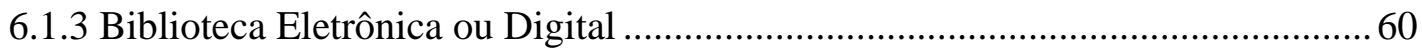

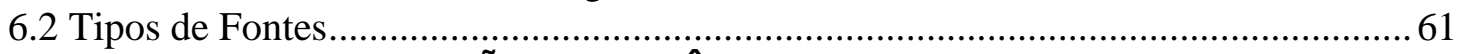

7. FONTES DE INFORMAÇÃO ELETRÔNICAS EM TURISMO............................64

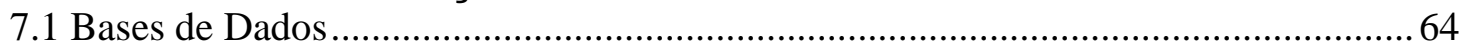

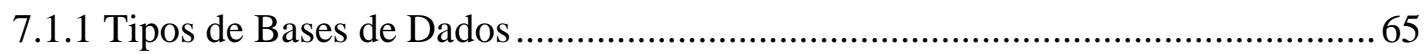

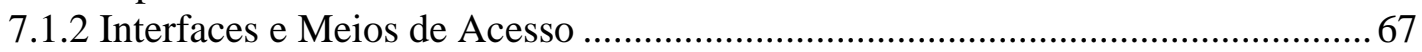

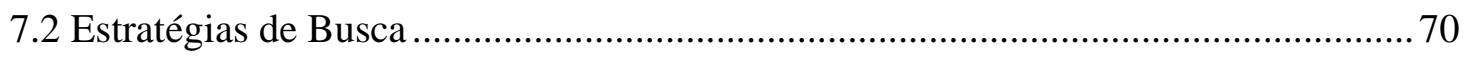

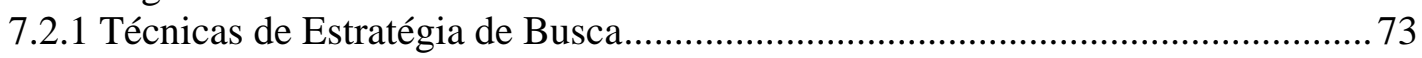

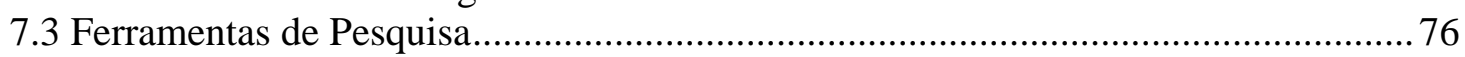

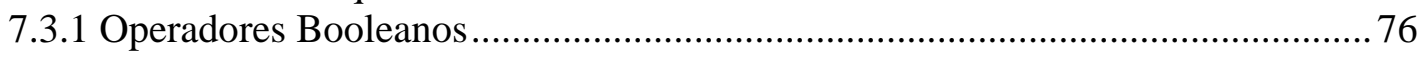

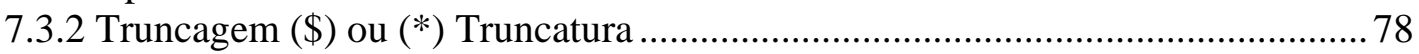

7.4 Manual de Pesquisa em Bases de Dados Bibliográficas .......................................... 78

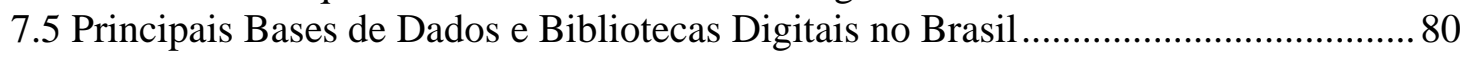

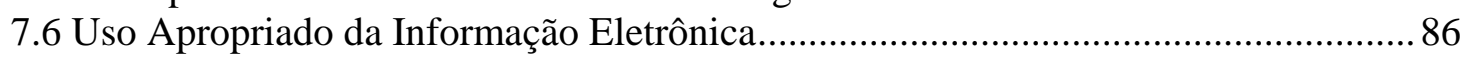

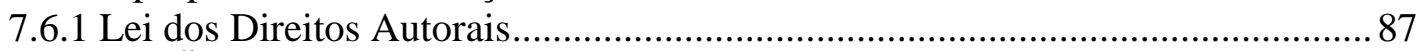

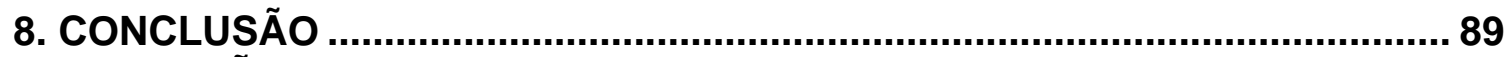

9. SUGESTÕES PARA ESTUDOS FUTUROS …........................................... 91

10. GLOSSÁRIO ...................................................................................... 92

11. REFERÊNCIAS BIBLIOGRÁFICAS ...................................................... 97 


\section{INTRODUÇÃO}

\footnotetext{
"Onde está a sabedoria que perdemos no conhecimento,onde está o conhecimento que perdemos na informação?".
}

(T. S. Eliot. Chorus from the rock. London: Faber, 1947)

A informação permeia todo o corpo da ciência. É para ela tão vital quanto a própria pesquisa, pois a esta não cabe reivindicar com legitimidade este nome até que seja analisada e aceita pelos pares. Isso exige, necessariamente, que seja comunicada. Ademais, o apoio às atividades científicas é dispendioso e, a menos que os resultados das pesquisas sejam direcionados aos usuários pertinentes, os recursos financeiros que são alocados a estas atividades continuarão a ser desperdiçados.

Atualmente, vivemos em um período de intensas transformações caracterizado pelo constante fluxo e troca de informações num ritmo cada vez mais acelerado de descobertas e aplicações.

Este estudo examina como tecnologias em constante mudança afetam as práticas de pesquisa no meio acadêmico referentes ao fenômeno turístico.

Sendo assim, o objetivo principal deste estudo é em primeiro plano analisar e contextualizar a informação para posteriormente oferecer um levantamento especializado na área de turismo, das principais fontes de informação eletrônicas com o intuito de orientar os pesquisadores desta área a localizarem e acessarem a informação desejada de forma ágil e eficiente.

Também serão abordadas considerações temáticas e metodológicas referentes aos resultados de pesquisas sobre a bibliografia da área. 
Segundo Ansarah $(2002)^{1}$, a educação superior no Brasil está sendo desafiada por novas possibilidades relacionadas ao emprego de tecnologias que têm melhorado os meios pelos quais o conhecimento pode ser produzido, controlado, administrado, difundido, acessado e utilizado. O que vem reforçar a importância do uso da tecnologia no acesso a informação relacionada à evolução do setor de turismo, sendo a acessibilidade à informação fator decisivo neste processo.

A informação acessível e disponível em forma eletrônica provoca alterações na maneira da busca, do acesso e da respectiva utilização. Emergem utilizações diferenciadas no ensino e na pesquisa face às novas tecnologias da informação e comunicação. Verifica-se a necessidade de analisar as condições de acesso e de uso de determinada comunidade para desencadear reflexões e apontar ações de melhoria pautadas na percepção das necessidades informacionais dos usuários no ambiente pesquisado.

Além disso, no processo de aquisição do conhecimento, a busca, o acesso e o uso de fontes de informação facilitam a solução de problemas informacionais e colaboram na geração e inovação do conhecimento. É preciso, então, conhecer quais os recursos utilizados e pertinentes. Ao defrontar-se com a oferta de informações disponibilizadas em suportes eletrônicos diversos, necessita-se saber como proceder nos diferentes ambientes para obter o máximo de proveito dos mesmos.

\footnotetext{
${ }^{1}$ ANSARAH, Marília Gomes dos Reis. Formação e capacitação do profissional em turismo e hotelaria: reflexões e cadastro das instituições educacionais do Brasil. São Paulo: Aleph, 2002. p. 15.
} 
Portanto, investigar o porquê da utilização das Tecnologias de Informação (TIC's), voltadas aos aspectos das necessidades informacionais de um determinado segmento, desencadeia reflexões sobre diversos fatores, quais sejam: identificar e caracterizar quais e como são utilizadas as fontes de informação eletrônicas, bem como avaliar questões referentes aos aspectos da necessidade e percepção do acesso e uso das informações pelos pesquisadores em turismo e na percepção de suas necessidades informacionais.

Espera-se, portanto, que os resultados obtidos com este estudo possam contribuir para a acessibilidade de fontes especializadas em turismo, revelando o "caminho das pedras" a ser percorrido pelos pesquisadores, além de subsidiar futuras pesquisas e estudos da área, em ações de fomento. 


\section{DELIMITAÇÃO DA PESQUISA}

\subsection{Definição do Problema}

Sabe-se que, atualmente, no Brasil, são parcos os recursos destinados à Ciência e Tecnologia (C\&T), e, que a ausência de políticas científicas que norteiem as ações das agências de fomento tende a agravar as atividades de pesquisa na área de Turismo.

Conforme Martins (1988), o conhecimento de determinada área da ciência permite ao pesquisador evitar a repetição de erros passados, a perda de tempo com repetição de pesquisas já realizadas, a concentração de grandes esforços em pesquisas secundárias, além de evitar a escolha de um projeto que apresente dificuldades insuperáveis.

Sendo assim, o estudo de um campo específico do conhecimento é extremamente relevante, não só para o desenvolvimento e formação de um constructo teórico sólido, mas também para facilitar o acesso à informação especializada pelos pesquisadores. E é isso que se pretende neste estudo, descrever a prática de pesquisa em fontes de informação eletrônica relativas ao fenômeno turismo e refletir sobre esta prática, com o intuito de diminuir a distância entre o pesquisador e a fonte de que necessita para transpor a informação, e chegar ao conhecimento, contribuindo para a tomada de decisões referentes à todo este processo de aquisição do conhecimento. 


\subsection{Justificativa}

Apesar da importância adquirida pelo turismo em todo mundo, este, como objeto de estudo é um fenômeno relativamente recente. Atualmente a base científica do turismo está em constante crescimento e este fenômeno está se transformando em um campo de investigação muito promissor. Desenvolver, então, um estudo capaz de otimizar o acesso às fontes de informação especializadas em Turismo, num país com escassos recursos documentais e com pouca tradição de pesquisa nessa área apresenta-se extremamente necessário.

Este estudo se realiza em um momento em que a área de Turismo demanda muitas frentes de pesquisa tanto no campo profissional quanto no campo teórico.

Justifica-se, assim, a proposta de um estudo descritivo relativo às fontes de informação especializadas em turismo.

\subsection{Objetivos}

\subsubsection{Objetivo Geral}

Analisar as condições gerais de disseminação e acesso às fontes de informação eletrônicas, propondo sugestões metodológicas e estratégicas que facilitem a busca informacional em Turismo.

O objetivo deste estudo é descrever e analisar o uso das fontes de informação eletrônicas disponíveis na área de turismo atualmente. 


\subsubsection{Objetivos Específicos}

- Ressaltar a importância do item informação na sociedade atual;

- Levantar questões e considerações acerca da comunicação da informação e seus processos;

- Identificar as fontes eletrônicas de informação na área de Turismo;

- Descrever o processo de busca da informação eletrônica em Turismo;

- Contribuir para maior divulgação dessas fontes;

- Diminuir as barreiras quanto ao acesso e uso da informação eletrônica;

- Descrever as etapas que envolvem a utilização de bases de dados;

- Possibilitar ao pesquisador em turismo maior rapidez, eficiência e precisão no acesso à enorme massa documental disponível atualmente;

- Contribuir para ações de fomento nesta área;

- Ativar a sistematização da busca e conseqüente recuperação da informação especializada em Turismo.

\subsection{Metodologia}

O procedimento metodológico adotado neste estudo foi do tipo descritivo, através de pesquisa documental, em todas as fases de investigação. 
A análise processou-se mediante a aplicação de critérios cronológicoespaciais, temáticos e outros, após conceituar e contextualizar a informação genericamente de forma a possibilitar o entendimento e uso das fontes de informação eletrônicas em Turismo atualmente, confrontando-a com setores que a moldam e que por ela são influenciados. Identificadas as fontes de informação especializadas na área, espera-se descrever o processo de busca e recuperação da informação eletrônica no âmbito do Turismo, levando em consideração o perfil do pesquisador, a natureza da pesquisa, as abordagens metodológicas a serem utilizadas pelos pesquisadores e a tendência atual das pesquisas. 


\title{
3. A INFORMAÇÃO
}

\author{
"A informação só será significativa, se vier acompanhada de \\ oportunidade, exatidão e relevância". (DAVENPORT, 1958)
}

\subsection{Conceituação}

A informação é um recurso, um bem com valores sociais, culturais, tecnológicos, econômicos e políticos, intangíveis. Toda ação ou decisão, em qualquer nível deve estar fundamentada em informação. A informação acompanha todos os processos da vida humana e os benefícios advindos de seu uso efetivo e facilidades de acesso são reconhecidos por todos.

Mas antes de tudo, a informação é um elemento dinâmico e transformador, portanto não é possível haver informação senão a partir de estímulos físicos, sociais ou culturais.

O seu objetivo é informar, este simples verbo provém do termo latim informare e significa etimologicamente dar forma a, dar vida a alguma coisa. Informar pressupõe, numa primeira etapa, o controle do conhecimento e, numa segunda etapa, a disseminação desse conhecimento.

Frente à evidência da grande gama de conceituações existentes para Informação e Conhecimento, nas mais diversas áreas do saber humano, a seleção de tais enfoques objetivou dar ampla cobertura a todos os aspectos do relacionamento entre Informação e Conhecimento, levando em consideração as definições de áreas diversas. 
Entre os vários autores que co-relacionam a epistemologia com a Ciência da Informação do ponto de vista filosófico, destaca-se Rafael Capurro ${ }^{2}$ e entre seus diversos trabalhos optei por focalizar principalmente dois: Epistemology and Information Science (1985); e What's Information Science for? A Philosofical Reflection, publicado em 1992.

No primeiro deles, Capurro (1985), busca, em São Tomás de Aquino, as raízes epistemológicas para o conceito de informação, afirmando ter sido Aquino quem cunhou o termo latim informatio implicando-lhe sentidos ontológico, epistemológico, pedagógico e lingüístico.

Segundo Aquino, o homem consiste de uma união íntima entre a matéria, que é uma potência, e a alma (anima), o princípio ativo que informa a matéria. O resultado dessa união, ou informação (no sentido ontológico da palavra) é um ser sensitivo e inteligente. Aquino aplica esse esquema à análise do conhecimento humano. Ele denomina o princípio do conhecimento de anima intellectiva, o qual inclui o princípio sensitivo, ou anima sensitiva. Conhecer um objeto significa a capacidade do intelecto passivo de compreender a espécies ou a forma do objeto, sendo que é o intelecto ativo que produz o ato de compreensão através da abstração do conceito universal advindo da forma representativa. As coisas materiais e sensíveis são compreendidas, à medida que, são apreendidas pelo sentido, representadas pela imaginação e tornadas inteligíveis pelo intelecto. Em

\footnotetext{
2 Rafael Capurro é pós-doutor em Filosofia Prática, pela Universidade de Stuttgart (Alemanha) e desempenha atividades nas áreas de Ciência da Informação e Ética da Informação, na Universidade de Ciências Aplicadas de Stuttgart. Além disso, é membro do European Group on Ethics in Science and New Technologies (EGE) e do World Technology Network (WTN).
} 
outras palavras, a compreensão (conhecimento) humana não é puramente intelectual nem puramente sensível, porém uma união de ambos.

Embora a filosofia moderna critique muitos aspectos deste paradigma, o termo informação tem aqui um importante papel, referindo-se à mediação entre a mente e os objetos à medida que eles são percebidos por nossos sentidos.

Ainda segundo Capurro (1992), o ponto de vista positivista no estudo da informação é sustentado por três paradigmas, a saber: o paradigma da representação, o paradigma emissor-canal-receptor e o paradigma platônico.

De acordo com o paradigma da representação, os seres humanos são conhecedores ou observadores de uma realidade externa. O processo de conhecimento consiste da assimilação de informações através de suas representações na mente humana. Essas representações, uma vez processadas ou codificadas em nossos cérebros, podem então ser comunicadas a outras mentes, armazenadas e processadas em máquinas (computadores).

O paradigma emissor-canal-receptor por sua vez trata o fenômeno da comunicação humana como uma metáfora a ser aplicada em diferentes níveis da realidade. Ao comunicarem-se, emissores e receptores trocam informação. Para que o receptor compreenda o significado da mensagem enviada pelo emissor, é necessário que exista um estoque de signos. De acordo com esse paradigma, a ênfase é voltada para o impacto da informação no receptor. Ao mesmo tempo, receptores são os pesquisadores ou usuários de informação com o objetivo de resolver seus problemas. 
O paradigma platônico apresenta um ponto de vista oposto aos dois anteriores: ao invés de considerar a existência de um sujeito detentor do conhecimento, considera a informação por si mesma. Pode ser materialista (o conhecimento não é um processo biológico, sociológico ou psicológico mas é objetivizado em transportadores não-humanos) ou idealista (o conhecimento é algo objetivo em si mesmo, independentemente de qualquer transportador material).

Grande parte das definições referentes ao termo informação de renomados autores nessa área do conhecimento baseiam-se em um desses paradigmas, ou numa mescla deles.

A abordagem tradicional, de acordo com Morris (1994) ${ }^{3}$, por exemplo, coloca a informação como externa, objetiva, alguma coisa que existe fora do indivíduo. Informação, nesse contexto clássico, existe em um mundo ordenado e é capaz de ser descoberta, definida e medida. Entretanto, alguns pontos importantes são desconsiderados nesta abordagem, a saber: em primeiro lugar, o conhecimento não é absoluto, em segundo plano, temos que considerar que as pessoas mudam constantemente e finalmente isto repercute na mensagem enviada que não é idêntica à recebida.

Historicamente a definição do termo informação e conhecimento sempre seguiram caminhos diferentes. Enquanto a informação era trabalhada pelas ciências exatas, sendo tratada como um conceito matemático para definir a

\footnotetext{
${ }^{3}$ MORRIS, R.C.T. Toward a user-centered information science. Journal of the American Society for Information Science, v. 45, n.1, Jan. 1994.
} 
comunicação, o conhecimento sempre foi trabalhado pela filosofia, sociologia e ciências humanas em geral.

Cardoso $(1996)^{4}$, a respeito do termo informação, afirma que o uso deste termo remonta à Antigüidade e que este sofreu, ao longo da história, tantas modificações em sua acepção, que na atualidade seu sentido está carregado de ambigüidade, sendo confundido freqüentemente com comunicação, outras tantas com dado, em menor intensidade com instrução e mais recentemente com conhecimento.

Contudo, Scotti $(1999)^{5}$ nos lembra que a informação, neste final de século tem se constituído num instrumento imprescindível ao desenvolvimento social, político e econômico dos países. [...] a informação e o conhecimento passam a constituir recursos econômicos fundamentais. Isto, aliado ao advento das tecnologias da informação, levou estes dois conceitos a se tornarem objeto de uma mesma área: a Ciência da Informação. Ou seja, o conceito de informação foi trazido para as ciências sociais e começou a ser trabalhado juntamente com o conceito de conhecimento. O fato é que é impossível falar-se em informação sem contemplar o termo conhecimento. Neste universo, surge o termo dado que também passa a ser objeto de estudo das Ciências Sociais.

\footnotetext{
4 CARDOSO, Ana Maria Pereira. Pós-Modernidade e informação: conceitos complementares? Perspectivas em Ciência da Informação, Belo Horizonte, v. 1, n. 1, p. 71, jan./jul. 1996.

${ }^{5}$ SCOTTI, E.V. et al. O terceiro milênio e o paradigma da informação. Encontros Bibli: Revista de Biblioteconomia e Ciência da Informação, Florianópolis, n. 8, set. 1999. Disponível em: < http://www.ced.ufsc.br/bibliote/encontro/bibli8/bibli8.html>
} 
Surgem, portanto, muitas definições e conceituações na literatura a respeito de informação, dados e conhecimento, que variam sensivelmente de autor para autor, dificultando um consenso na definição do termo informação.

Neste ambiente totalmente ambíguo, onde se associam termos definidos tão diversamente, que precisam ser definidos de uma maneira uníssona para que possam ser trabalhados e estudados aos olhos de uma mesma ciência, surgem, inevitavelmente polêmicas e tentativas de construções teóricas mais consolidadas.

Para tanto, apesar de minha resistência inicial, julguei por bem fazer a velha distinção entre dados, informação e conhecimento, apesar da nítida imprecisão entre elas, até porque penso que a informação é um termo que engloba todos os outros, além de servir como conexão entre eles.

Recentemente, Setzer $(1999)^{6}$, no desenvolvimento de um projeto que visava informatizar aspectos da gestão do conhecimento em uma empresa, sugeriu a distinção entre os termos dados, informação e conhecimento, em que o primeiro tem caráter sintático, o segundo, semântico e o terceiro, pragmático.

De acordo com Setzer (1999), dado “[...] é uma seqüência de símbolos quantificados ou quantificáveis". Como são símbolos quantificáveis, dados podem ser armazenados em um computador e processados por ele. "[...] em nossa definição, um dado é necessariamente uma entidade matemática e, desta forma, puramente sintática". Sendo assim, um dado é puramente objetivo, não dependendo do seu usuário.

\footnotetext{
${ }^{6}$ SETZER, V. Dado, informação, conhecimento e competência. DataGramaZero . Revista de Ciência da Informação, n. 0, dez. 99. Disponível em: <http://www.dgz.org.br/dez99/F_I_art.htm>
} 
Pois bem, dados podem ser entendidos como registros ou fatos em sua forma primária, não necessariamente físicos. Uma imagem guardada na memória, por exemplo, é um dado.

Quando esses dados são organizados ou combinados de forma significativa, eles se transformam numa informação. De acordo com McGee e Prusak (1994) ${ }^{7}$, informação consiste em dados coletados, organizados, orientados, aos quais são atribuídos significados e contexto.

Na mesma linha, Peter Drucker $(1988)^{8}$ definiu informação, com eloqüência, como "dados dotados de relevância e propósito".

Setzer (1999) vai mais além ao caracterizar a informação como [...] uma abstração informal, que representa algo significativo para alguém através de textos, imagens, sons ou animação". Esta não é uma definição, isto é uma caracterização, porque algo significativo e alguém não estão bem definidos, gerando aqui um entendimento intuitivo desses termos. "[...] não é possível processar informação diretamente em um computador, para isso é necessário reduzí-la a dados". Uma distinção entre dado e informação é que o primeiro é puramente sintático e o segundo contém necessariamente semântica. "[...] a informação é objetiva e subjetiva no sentido que é descrita de uma forma objetiva, mas seu significado é subjetivo, depende do usuário".

\footnotetext{
7 McGEE, James; PRUSAK, Laurence. Gerenciamento estratégico da informação: aumente a competitividade e a eficiência de sua empresa utilizando a informação como uma ferramenta estratégica. Rio de Janeiro: Campus, 1994.

${ }^{8}$ DRUCKER, Peter F. The coming of the new organization. Harvard Bussiness Review 66, janeirofevereiro de 1988, p. 1-2.
} 
Davenport (2001) ${ }^{9}$ e Prusak (1998) conceituam o conhecimento como "uma mistura fluida de experiência condensada, valores, informação contextual e insight experimentado, a qual proporciona uma estrutura para a avaliação e incorporação de novas experiências e informações".

Já para Setzer (1999), o conhecimento é "[...] uma abstração interior, pessoal, de alguma coisa que foi experimentada por alguém, não podendo ser descrito inteiramente, de outro modo, seria apenas dado ou informação". Sendo assim, o conhecimento não depende apenas de uma interpretação pessoal, mas requer uma vivência do objeto do conhecimento, não podendo ser inserido em um computador por meio de uma representação, pois desta forma, seria reduzido a uma informação. Setzer (1999) associa informação à semântica e conhecimento à pragmática, quando diz que: “[...] o conhecimento é puramente subjetivo, cada um tem a experiência de algo de uma forma diferente".

Portanto, podemos inferir que da mesma forma que a informação é produzida a partir de dados carregados de relevância e propósito, o conhecimento também tem como origem a informação, quando a ela são agregados outros elementos.

Assim, consideramos o conhecimento como algo teórico e mais generalizado, e informação como conhecimento potencial.

Não obstante, o conhecimento costuma ser classificado tradicionalmente, como explícito ou tácito. Conhecimentos explícitos são aqueles que podem ser transformados em documentos, roteiros e treinamentos. Conhecimento tácito é

\footnotetext{
${ }^{9}$ DAVENPORT, Thomas H. Ecologia da informação: porque só a tecnologia não basta para o sucesso na era da informação. São Paulo: Futura, 2001.
} 
aquele difícil de registrar, documentar ou ensinar a outras pessoas, é de difícil transmissão ou descrição.

Apesar das diferenças de conceituação, pode-se identificar um entendimento comum: um conjunto de dados não produz necessariamente uma informação nem um conjunto de informações representa necessariamente um conhecimento.

Observa-se, entre esses termos, uma variação com relação ao grau de complexidade e relevância de cada um: transformam-se dados em informação agregando-se valor a eles; e informação em conhecimento acrescentando-se a ela vários outros elementos. A figura a seguir tenta reproduzir a hierarquia relacionada à informação.

\section{DADOS}

- Facilmente estruturados;

- Facilmente transferíveis;

- Facilmente armazenados em computadores.

\section{CONHECIMENTO}

- Dificilmente estruturado;

- Dificilmente capturado em computadores;

- Pode ser explícito ou tácito.

\section{INFORMAÇÃO}

- Dados dotados de significado;

- Exige consenso em relação ao significado.

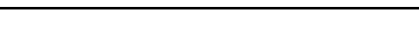

PRAGMÁTICO

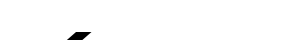


Fig. 1: Hierarquia informacional.

Esta visão dos conceitos, dado, informação e conhecimento, apresentadas anteriormente, tentam clarear suas delimitações e estabelecer de forma um pouco mais lógica a relação entre eles.

Dessa forma, informação e conhecimento apresentam-se como entidades distintas, pois, assim como a informação pode ser fruto de um conhecimento acumulado, o conhecimento pode ser fruto de informação assimilada, ou seja, estes podem existir independentes um do outro, pois como nos lembra Setzer (1999), o conhecimento está no usuário e não no conjunto de informações, uma vez que o conhecimento está incorporado nas pessoas e a criação de conhecimento ocorre ou não durante o processo de interação social.

Observa-se que, em estudos e trabalhos que necessitem utilizar esses termos, suas definições, ainda hoje, variam de acordo com a aplicação. O importante é ressaltar que, apesar de serem termos que muitas vezes se confundem, são conceitos ao mesmo tempo distintos e complementares.

Prosseguindo com o desafio de construir conceitos interdisciplinares neste ambiente tão multidisciplinar, onde se mesclam conceitos de áreas tão diversas (como exatas e humanas), buscamos na literatura especializada algumas definições sobre o termo informação, que são elencadas a seguir. Estas definições são muito influenciadas pela doutrina da teoria da informação. Apesar da teoria da informação não estar diretamente envolvida com valores e significados da forma como são em geral entendidos nas ciências sociais, ou na vida cotidiana, suas idéias e percepções ajudam no estudo da informação em qualquer contexto. 
Com o surgimento da informática, Shannon e Weaver $(1975)^{10}$ procuraram dar um significado matemático à informação. Preocuparam-se em estudar as formas físicas de transmissão da informação e, nesse sentido, acabaram tratando a informação como sinônimo de comunicação de dados.

Claude Shannon (1975) acredita que a informação é:

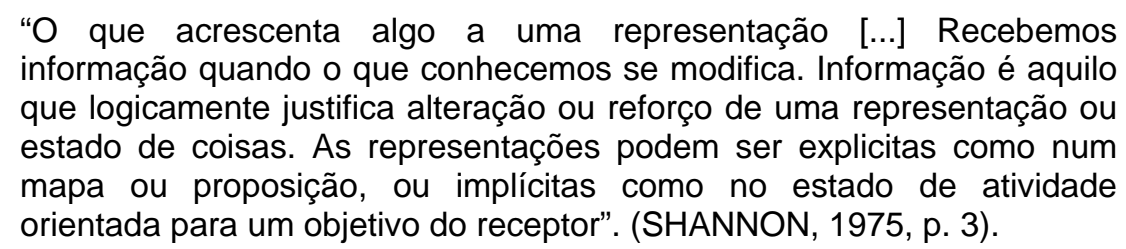

Segundo o conceito proposto por Norbert Wiener $(1960)^{11}$, fundador da cibernética, a informação "é o termo que designa o conteúdo daquilo que permutamos com o mundo exterior ao ajustar-nos a ele, e que faz com que nosso ajustamento seja nele percebido".

Para George Miller $(1996)^{12}$, informação é algo de que necessitamos quando deparamos com uma escolha. Qualquer que seja seu conteúdo a quantidade de informação necessária depende da complexidade da escolha. Se depararmos com um grande espectro de escolhas igualmente prováveis, se qualquer coisa pode acontecer, precisamos de mais informação do que se encarássemos uma simples escolha entre alternativas.

\footnotetext{
10 SHANNON, Claude; WEAVER, Warren. A teoria matemática da comunicação. São Paulo: DIFEL, 1975, p. 3.

${ }^{11}$ WIENER, Norbert. The human use of human beings: cybernetics and society. Cambridge, Mass.: MIT Press, 1960, p. 25.

${ }^{12}$ MILLER, George. The psychology of communication. Harmondsworth: Penguin Books, 1996, p.8.
} 
Para McKay $(1969)^{13}$, informação refere-se não tanto ao que você diz, mas ao que poderia dizer. Ou seja, informação "é a medida da liberdade de escolha quando se seleciona uma mensagem".

Concluímos que a polissemia do conceito de "informação" parece ser uma decorrência natural da apropriação do termo por diferentes áreas do conhecimento, de forma que para vincularmos o conceito ao contexto proposto por este estudo, delimitamos que, a informação é conhecimento fragmentado para sua melhor assimilação e disseminação, principalmente em meio eletrônico. Já o conhecimento é todo o saber existente nos seres e na natureza que é explicitado através de sua fragmentação em informação.

Mas o que é marcante nas diferentes definições é o emprego metafórico de estruturas. A metáfora, junto com a analogia constitui fato importante na maneira como solucionamos problemas e refletimos sobre o mundo. É a forma como explicamos as coisas para nós mesmos, e para os outros, comparando conceitos que se parecem, mas não são completamente idênticos. Daí a dificuldade em unificar e homogeneizar conceitos.

Sendo assim, qualquer que seja o conceito utilizado fica implícito que há uma realidade externa a nós que é a origem daquilo que resolvemos chamar 'informação', e que existe um 'eu' que alega empregar esta informação para vários tipos e formas de conhecimento, uma vez que, somos seres humanos e decidimos que informação absorvemos ou rejeitamos.

\footnotetext{
${ }^{13}$ McKAY, Donald. Information mechanism and meaning. Cambridge: Mit Press, 1969, p. 8.
} 


\subsection{Fluxo Informacional}

Levando em consideração todas as referências bibliográficas levantadas até então, subentendemos que a informação gera conhecimento, que por sua vez gera desenvolvimento, que vem a gerar nova informação.

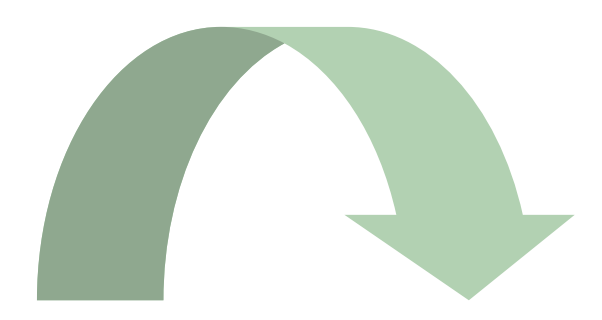

INFORMAÇÃO

CONHECIMENTO
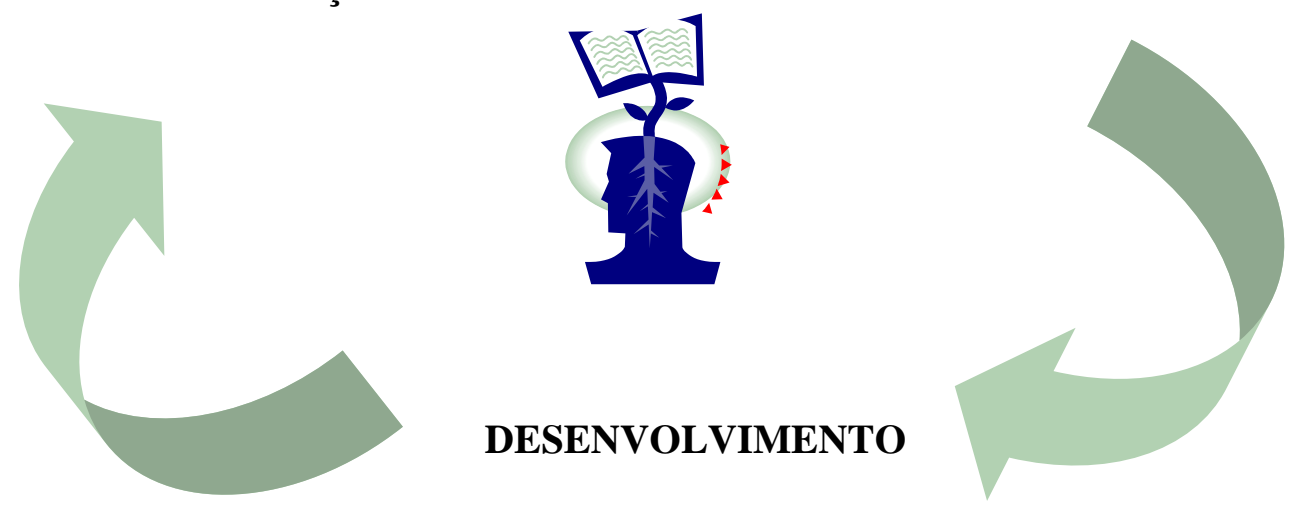

Fig. 2: Fluxo informacional.

Nesse sentido, consideramos que a informação é algo que um indivíduo gera ativamente e que outro indivíduo pode decidir internalizar, sendo que cada indivíduo recebe e interpreta informação da sua própria maneira, dando-lhe, significado pessoal. Além disso, a percepção da informação é mediada pelo estado de conhecimento do receptor, de forma que, quando a informação é 
percebida e recebida, ela afeta e transforma o estado de conhecimento do receptor.

\subsubsection{O Processo de Comunicação da Informação}

De maneira global, as ciências, tanto da matéria, da vida, quanto do homem ou da sociedade e da informação, enquanto atividades sociais, são, portanto, produtoras e utilizadoras de conhecimentos científicos e técnicos ${ }^{14}$. Como lembrado por Le Coadic $(2004)^{15}$, o sistema de pesquisas assemelha-se muito a um sistema econômico. Pode-se assim representá-lo a partir do esquema econômico clássico: produção - distribuição - consumo. Ressalvamos que estamos fazendo uma analogia de fenômenos, mas não de conceitos, pelo que falaremos mais de construção do que produção de conhecimentos. Construção, portanto, dos conhecimentos científicos e tecnológicos que se tornarão uma vez registrados, em forma escrita ou oral, impressa ou digital, informações científicas e tecnológicas. Pelo mesmo motivo, para descrever as outras duas fases do que denominamos ciclo da informação (ver figura 3), utilizaremos a palavra comunicação ao invés de distribuição, e uso em vez de consumo.

Choo $(2003)^{16}$ menciona, que o uso da informação ocorre quando o indivíduo "seleciona e processa informações ou mensagens que produzem uma

\footnotetext{
${ }^{14}$ Nas nomenclaturas econômicas elas são chamadas de "pesquisa científica e tecnológica".

${ }^{15}$ LE COADIC, Yves-François. A Ciência da Informação. Brasília: Briquet de Lemos, 2004.

${ }^{16} \mathrm{CHOO}$, Chun Wei. A organização do conhecimento. São Paulo : SENAC, 2003, p.118.
} 
mudança na capacidade de vivenciar e agir ou reagir à luz de novos conhecimentos".

Dessa forma, os três processos: construção - comunicação - uso, se sucedem e se alimentam reciprocamente.

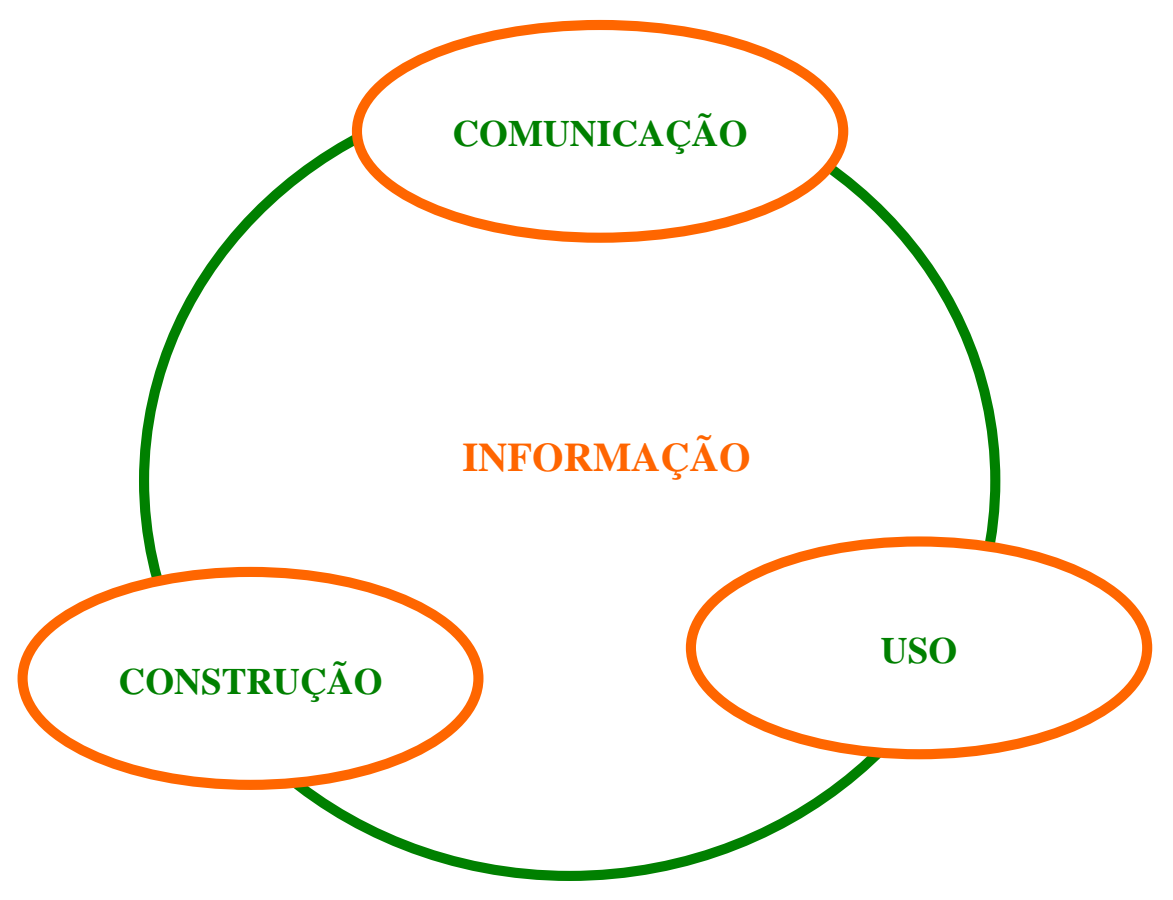

Fig. 3: Ciclo da informação.

Esta estrutura possibilita um novo paradigma, face aquele esquema tradicional e mais simplista representado pelos meios de comunicação de massa, que restringe a comunicação a uma relação bilateral: informador - informado, conforme ilustrado pela figura seguinte. 


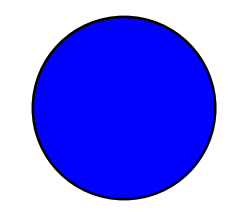

INFORMADOR

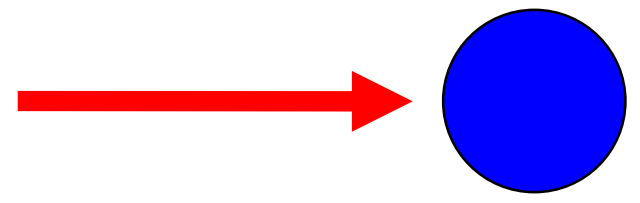

INFORMADO

Fig. 4. Meios de comunicação de massa

Rompe também com o modelo da teoria da informação, que mantém um padrão linear apesar do aprimoramento proposto ao inserir a mensagem no modelo. Apesar disto, a "modelização física" (fig. 3) está distante de se transformar em um modelo de comunicação social como o proposto pela fig. 5 .

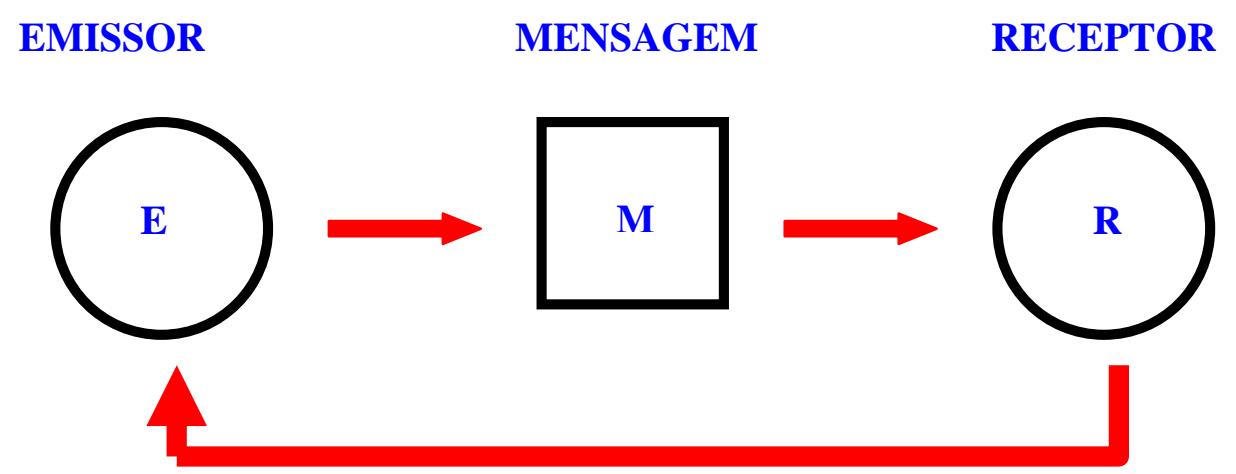

Fig. 5. Teoria da informação 
Assim, a comunicação é descrita como o processo intermediário que permite a troca de informações entre os usuários. Finalmente, destacamos a definição de Escarpit $(1990)^{17}$, para concluir que a comunicação é um ato, um processo, um mecanismo, e que a informação é um produto, uma substância, uma matéria.

\subsection{A Representação da Informação}

Parafraseando McGarry $(1999)^{18}$, a informação deve ser ordenada, estruturada ou controlada de alguma forma, caso contrário, permaneceria amorfa e inutilizável. A razão disso recai em nossa condição de seres humanos, ou seja, nas nossas limitações sensoriais.

Sabemos que a informação dispersa não constitui inteligência, pois apenas a partir da estruturação da informação é que a inteligência passa a existir. Assim, a premissa básica para se fazer inteligência é agregar valor à informação, é estruturá-la de modo que a mesma passe a ter um valor, uma importância contextual.

Para tanto a informação, qualquer que seja, precisa ser representada e estruturada para nós de alguma forma, e transmitida por algum tipo de canal. A informação, portanto, deve ter alguma forma de 'veículo', condução. Este veículo deve possuir um atributo essencial para que possa ser compreendido pelo

\footnotetext{
${ }^{17}$ ESCARPIT, R. Théorie générale de l'information et de la communication. Paris: Hachette, 1990.

${ }^{18}$ McGarry, Kevin. O contexto dinâmico da informação: uma análise introdutória. Tradução de Helena Vilar de Lemos. Brasília: Briquet de Lemos, 1999.
} 
receptor. Deve ser discriminável. Em palavras mais simples, é preciso que o receptor possa distinguí-lo dos fenômenos que o cercam. Para tanto, existem três classes de veículos responsáveis pela transmissão de informações.

$>$ Sinais;

Signos;

Símbolos.

Rigorosamente falando, o sinal é uma forma de signo que enfatiza a necessidade de que será seguido por algum tipo de ação, e que requer algum tipo de ação do receptor. Em termos gerais, um sinal é comunicado de uma pessoa a outra para indicar que o momento de agir está próximo. Um exemplo cotidiano do emprego de sinais pode ser observado quando dirigimos um carro. Sinalizamos que o momento e o local para determinada ação estão próximos.

Já o signo, é um indício físico da presença imediata da ação ou evento que representa. A fumaça, por exemplo, é sinal de fogo. É como se a ação fosse percebida com um significado propositalmente combinado. Há vários exemplos disso na comunicação não-verbal, onde um gesto convencional pode significar uma palavra ou idéia.

Quanto aos símbolos, estes representam um tipo especial de signo. Representam um objeto, idéia ou evento, mas ao contrário do signo, o símbolo tem um significado duradouro que o transcende. $\mathrm{O}$ aspecto fundamental que $\mathrm{o}$ diferencia dos signos é o de ser representações, culturalmente construídas e aceitas, de coisas, idéias e aspirações, sendo que seus significados variam dependendo do grupo social que os utiliza. Uma cruz no código de trânsito indica que há um cruzamento iminente, e é também o símbolo da cristandade. 
Signos e símbolos são repetidamente usados de forma intercambiável, mas de acordo com os lógicos deve-se estabelecer uma distinção entre aquilo que representa outra coisa devido a uma semelhança natural ou relação associativa (fumaça como indício de fogo) e aquilo que recebeu um significado culturalmente construído, como, por exemplo, a fumaça de uma cerimônia de cremação como símbolo de ritual religioso.

Todo este rodeio acerca de definições justifica-se para traçar uma conexão entre as principais características dos símbolos e as funções que estes exercem na comunicação humana, uma vez que, são utilizados na transmissão, intercâmbio e registro de significados e compreensão humanos. Além disso, os símbolos funcionam como repositórios de significados dentro de uma cultura, sem eles os seres humanos seriam presas do tempo e incapazes de armazenar sua cultura registrada. Mas além de servirem como repositórios de significados compartilhados, as formas simbólicas funcionam como unificadoras dentro e através de grupos sociais e culturais, permitindo que as pessoas lidem com mundos que estejam além de suas experiências sensoriais imediatas, construindo meios que lhes permitam dar sentido a essas experiências.

Imaginemos por um momento a última biblioteca que consultamos. Os livros e materiais afins foram colocados numa ordem preestabelecida, senão seu valor como informação seria perdido ou irrecuperável. Entre as capas de livros, revistas, recursos audiovisuais e bases de dados encontram-se signos e símbolos de vários tipos, formando uma combinação de signos gráficos, símbolos visuais, signos e símbolos matemáticos e signos eletrônicos, todos criados por outros seres humanos. Podemos deduzir então que nossa compreensão da informação 
fornecida por estes signos e símbolos é condicionada pela informação visual estruturada e representada.

De qualquer forma, a informação interfere em todos os níveis da percepção humana, pois é a base da educação, da capacitação e da formação ideológicocultural das pessoas. A informação é um recurso fundamental que afeta todas as atividades da sociedade e, no mundo atual, ela é instrumento capaz de alterar um estado estático do conhecimento, permitindo a identificação de problemas, a busca de alternativas e soluções, a tomada de decisões e, finalmente a avaliação de resultados. Portanto aqueles que lidam com a informação exercem um papel delicado na sociedade. Além disso, a informação permeia todos os níveis de uma organização e está enraizada em todas as atividades individuais do ser humano. 


\title{
4.A ERA DA INFORMAÇÃO
} "Vivemos num tempo atônito que ao debruçar-se sobre si próprio
descobre que os seus pés são um cruzamento de sombras, sombras
que vêm do passado que ora pensamos já não sermos, ora pensamos
não termos ainda deixado de ser, sombras que vêm do futuro que ora
pensamos já sermos, ora pensamos nunca virmos a ser".

(SANTOS, 2005)

\subsection{Sociedade da Informação}

\begin{abstract}
"Na última década do século XX, uma nova grande mudança chega com as redes cibernéticas que vêm revolucionar todo o status quo conhecido até então, da economia à comunicações, passando a configurar uma realidade que passou a ser chamada de sociedade da informação, ou era da informação".

(PERUZZO, 2002)
\end{abstract}

A sensação ou a consciência de que o mundo está mudado, que os tempos são outros, é sem dúvida, anterior ao conhecimento do nome que foi dado a este momento histórico. Momento este sobre o qual a sociedade e a informação parecem influir, a tal ponto que acabou por assumir seu nome ao se tornar 'sociedade da informação', abandonando os qualificativos bastante sólidos de 'industrial', herdado do século XIX, depois passando para 'pós-industrial', até inaugurar a era da informação e a era do setor quartenário ${ }^{19}$.

Refletir sobre a pós-modernidade é pensar a respeito das coisas no instante em que elas acontecem. Falamos acerca do agora, ao mesmo tempo em que o vivemos. O debate está no ar. Pós-moderno, pós-utópico, pós-industrial, sociedade da informação, era da informação... Ruptura ou continuidade, eis a questão.

${ }^{19}$ Machlup, F. The production and distribution of knowledge in the United States. Princeton: University Press, 1972. 
A mudança mais significativa que ocorre na ambiência é o que se convencionou chamar, entre outras denominações, de sociedade pós-industrial. Esta se refere essencialmente às mudanças na estrutura social, às transformações que se produzem na vida econômica, na estrutura profissional e às relações que se estabelecem entre a teoria e a prática experimental, entre ciência e tecnologia.

O modus operandi da sociedade pós-industrial identifica-se com o da sociedade da informação. Trata-se de um modo de desenvolvimento social e econômico em que a aquisição, armazenamento, processamento, valorização, transmissão, distribuição e disseminação da informação conducente à criação de conhecimentos e à satisfação das necessidades dos usuários e das organizações desempenham um papel central na atividade econômica, na criação de riqueza, na definição da qualidade de vida das pessoas e de suas práticas culturais.

Lyotard $(1979)^{20}$ iniciou a polêmica sobre o assunto, publicando "La condition postmoderne", que discorre sobre o saber nas sociedades mais desenvolvidas, sociedades estas que detêm altas tecnologias e conseqüentemente produzem mais informações.

Sob a forma de mercadoria informacional indispensável ao poderio produtivo, o saber já é e será um desafio maior, talvez o mais importante, na competição mundial pelo poder. Do mesmo modo que os Estadosnações se bateram para dominar territórios, e com isso dominar o acesso e a exploração das matérias-primas e da mão de obra barata, é concebível que eles se batam no futuro para dominar informações. (LYOTARD, 1985, p. 5)

${ }^{20}$ LYOTARD, Jean François. La condition post-moderne: rapport sur le savoir. Paris: Éd. de Minuit, 1979. p. Xvii. 
Conforme Lyotar (1979), como conseqüência do ingresso das sociedades na chamada era pós-industrial e das culturas na chamada era pós-moderna ${ }^{21}$, houve uma mudança na condição do saber. O autor faz a oposição entre a ciência moderna, legitimadora do consenso e da unanimidade, e a ciência na condição da pós-modernidade, como sendo "a incredulidade em relação aos metarrelatos ${ }^{22 ",}$ que "aguça nossa sensibilidade para as diferenças e reforça nossa capacidade de suportar o incomensurável". É o momento do dissenso e da legitimação por paralogismos $^{23}$. Assim, outros elementos são introduzidos como legitimadores dessa deslegitimação: são os jogos de linguagem, caracterizados pela heterogeneidade, e dissenso. O saber pós-moderno não é somente o instrumento dos poderes...! Ele mesmo não encontra sua razão de ser na homologia dos 'experts', mas na paralogia dos inventores.

Habermas (1987) ${ }^{24}$ respondeu prontamente, acusando Lyotard de rejeitar o mundo moderno e as grandes narrativas históricas. Rotulou de "jovens conservadores" a corrente do pensamento francês, que seguia o caminho aberto por Nietzsche, pregando a desconstrução do discurso, dos valores ocidentais e da verdade defendida pelo pensamento liberal. Habermas incluiu, nesta tipologia, pensadores como Derrida, Deleuze, Foucault, e, conseqüentemente, Lyotard.

\footnotetext{
${ }^{21}$ As rupturas da ciência moderna são abordadas de maneira didática por Santos, Boaventura de Sousa. Introdução a uma ciência pós-moderna. Rio de Janeiro: Graal, 1989.

22 São ideologias, certezas, orientações que serviam para guiar grupos e indivíduos nas diversas questões sócio-políticas.

${ }^{23}$ Raciocínios que não são válidos.

${ }^{24}$ Para maior aprofundamento no tema consultar HABERMAS, Jurgen. A modernidade: um projeto inacabado? Crítica. Lisboa, n. 2, p. 5-23. nov. 1987.
} 
Habermas considera, ainda, que o que se convencionou chamar pósmodernidade é um impasse político-cultural ou uma transição difícil na realização do projeto emancipador, ainda incompleto, da modernidade, que tem como força propulsora uma nova "racionalidade comunicativa democratizadora", que se sobreporá à racionalidade instrumental.

Ainda que apresentadas sucintamente, estas são formas diferentes de se pensar e conceituar o momento atual ${ }^{25}$. Polêmicas à parte, o fato é que grandes modificações aconteceram e estão diante de nossos olhos. Não há como negálas. É provável que a pós-modernidade já estivesse em germe na modernidade. Neste sentido, seria a conseqüência ou a intensificação de características latentes no período anterior.

De qualquer forma é fato que, assim como observou Sevcenko (1987) ${ }^{26}$, a condição pós-moderna abre espaço para "o aprendizado humilde, que já tarda, da convivência difícil, mas fundamental com o imponderável o incompreensível, o inefável".

O sociólogo americano Daniel Bell ${ }^{27}$ propõe um esquema comparativo entre as sociedades pré-industrial, industrial e pós-industrial (pós-moderna). Esta última se alicerça na economia terciária - serviços, saúde, consumo, educação, comunicação - onde a informação e a manipulação do conhecimento assumem

\footnotetext{
${ }^{25}$ Para entender melhor o momento ler YUDICE, Jeorge. O pós-moderno em debate. Ciência Hoje. Rio de Janeiro, v.11, n. 62, p. 46-57, mar. 1990.

${ }^{26}$ SEVCENKO, Nicolau. O enigma pós-moderno. IN: OLIVEIRA, Roberto Cardoso et.al. Pósmodernidade. Campinas: Ed.Unicamp, 1987. p.54.

${ }^{27}$ BELL, D. The coming of pós-industrial society: a venture in social forecasting. Nova lorque: Basic Books, 1973.
} 
papel vital para o desenvolvimento técnico e científico, impondo novas bases para o capitalismo internacional.

O contorno da economia mundial é traçado, agora, pela quantidade de informação possuída, veiculada e divulgada, resultante da produção científica e tecnológica, que por sua vez significam novos "inputs" alimentando o ciclo.

Com o surpreendente salto das descobertas tecnológicas dos últimos vinte anos, é possível a obsolescência de um produto ainda na linha de montagem. Daí a necessidade da circulação veloz da informação, especialmente, a tecnológica.

Além da velocidade imprimida ao processo de descobertas científicas e tecnológicas, existe outra diferença fundamental entre a ciência moderna e a pósmoderna. Esta última como já mencionamos, não se supõe sustentadora da verdade e legitimadora do saber, não crê nos metarrelatos.

Neste sentido, toda essa paralogia produz grande volume de informações, fato que exige maior quantidade de meios de transmissão, fundamentais para originar novas idéias e inventos. Neste novo paradigma ${ }^{28}$, a informação adquire maior importância que a realidade concreta, conhecida, muitas vezes, tão somente através dos veículos de transmissão. O valor do real é transferido para o que se conhece a seu respeito, as informações que se tem dele. Assim, a informação e o conhecimento passam a ser as "mercadorias" mais requisitadas do capitalismo no estágio pós-moderno.

\footnotetext{
${ }^{28}$ Na obra intitulada A estrutura das revoluções científicas, Thomas Kuhn (1992) realizou um estudo da evolução das ciências no qual identifica duas formas pelas quais a ciência progride: por evolução e por revolução. A revolução ocorre na mudança de idéias fundamentais de uma ciência, levando a um total redirecionamento nos estudos. A estas idéias fundamentais Kuhn denominou de paradigmas.
} 
Se, na fase anterior, a tecnologia básica era a energia transformada em bens de consumo pela indústria, na contemporaneidade pós-moderna a tecnologia é a informação, a informatização e a codificação ou representação do conhecimento. Este é o motivo que gera a criação de sistemas altamente avançados de processamento, armazenamento e recuperação da informação, inclusive, a longa distância.

Castells (2002) ${ }^{29}$ evidencia questões de "background", o poder fértil da informação, capaz de concretizar uma nova estrutura social. Nesse sentido, julga necessário esclarecer a distinção entre sociedade da informação - aquela que recebe os impactos informacionais e sociedade informacional - aquela cuja estrutura básica é apresentada em redes, divisão típica da nova sociedade em rede que vem sendo difundida sobre o planeta reivindicando uma universalidade sem paralelo, a sociedade em rede e suas relações.

Ainda segundo Castells (2003), numa economia eletrônica baseada no conhecimento, na informação e em fatores intangíveis (como imagem e conexões), a inovação é a função primordial. Essa inovação diz respeito à relação das pessoas com as tecnologias, aos processos e aos produtos. As redes de relações humanas são dinamizadas e impulsionam a disseminação e o fluxo da informação em diversas comunidades.

Nesse contexto, certamente, o que se espera da sociedade da informação é a circulação da informação é que esta ao ser utilizada produza soluções

\footnotetext{
${ }^{29}$ CASTELLS, Manuel. A era da informação: economia, sociedade e cultura. 3. ed. São Paulo: Paz e Terra, 2002.
} 
pertinentes para os diversos problemas existentes na diversidade cultural, educacional e econômica.

\subsection{Tecnologia da Informação}

"A informatização da sociedade é necessária e irreversível".

(TRIGO, 2001)

Vimos, no primeiro capítulo, a dificuldade de definir informação e o perigo de conceituá-la erroneamente. Vimos também que a teoria da informação nos dá algumas percepções úteis sobre os efeitos da informação, sendo que um dos mais úteis é o conceito de incerteza. Sim, a incerteza, pois, é quase sempre uma fonte de tensão, e a redução dessa incerteza, por menor que seja, será sempre bemvinda, principalmente em situações novas ou inusitadas.

A tecnologia vem ocasionando profundas transformações nos procedimentos de produção, transmissão e uso da informação. No atual momento, encontra-se em andamento uma revolução quanto aos princípios que orientam as organizações sociais, sendo que, no processo evolucionário, a informação e o conhecimento transformam-se em chaves do novo paradigma.

Já em 1959, John Rader Platt, investigador da Universidade de Chicago, acrescentou às tradicionais necessidades do homem: ar, água, alimentação e abrigo, "um quinto fator essencial a sobrevivência física, que é a necessidade de informação, de um fluxo de estímulos contínuo, novo, imprevisível, não redundante, e surpreendente". Assim, para essa constante busca de algo que possa alimentar esse impulso básico, a ação de comunicação tornou-se uma 
atividade essencial e inevitável, proporcionando constante provisão e assimilação de novas informações. Para atender a esse impulso natural, no decorrer de sua evolução, foram sendo concebidas formas de registros que pudessem efetuar a preservação e a transferência de informação, transcendendo o espaço e o tempo, tornando-a independente da memória humana e do contato físico e consolidandoa de geração a geração.

Com o advento dos meios eletrônicos ${ }^{30}$, pelos idos da década de 1960, transformações fundamentais ocorreram no processo de comunicação e pesquisa científica.

Conforme mencionado por Cunha $(1993)^{31}$, o grande salto quantitativo dos tipos de materiais bibliográficos, conhecido como o "boom informacional", ocorreu devido à crescente importância na sociedade moderna do item informação, tornando-se um produto estratégico no desempenho, interação e sinergia no processo social e econômico, transformando-se, nos anos 60, em um novo setor definido como o do conhecimento ou da informação. Em conseqüência, o volume sempre crescente de informações e suportes tem levado as organizações, responsáveis pelo tratamento, organização e recuperação da informação, à criação de mecanismos para possibilitar o uso dessa grande "massa" de dados disponíveis.

\footnotetext{
${ }^{30}$ Todo o processo evolucionário dos meios eletrônicos encontra-se minuciosamente descrito na obra de: CASTELLS, Manuel. A sociedade em rede. 7. ed. São Paulo: Paz e Terra, 2003.

31 CUNHA, Murilo Bastos da; ROBREDO, Jaime. Necessidade de integração das políticas de informação no Mercosul. Ciência da Informação, v.22, n.1, p.7-12, 1993.
} 
O computador passou então a ser empregado no processamento de informações e sua evolução possibilitou o tratamento rápido de uma grande quantidade de informações, além de permitir a "circulação" da informação de forma quase instantânea, transformando-o em ferramenta cada vez mais eficaz para a comunicação científica.

As novas TIC's, incorporadas ao cotidiano, provocam profundas mudanças e causam transformações que necessitam serem analisadas, compreendidas e assimiladas no contexto real de uma sociedade dinâmica, no qual o fluxo de informações é impulsionado pela velocidade no acesso e uso da informação.

Hoje, além da mídia, contamos com avançados meios eletrônicos e virtuais que possibilitam obter a informação em poucos segundos. Uma novidade da atualidade refere-se à tecnologia digital que agora domina o universo social da informação. $\mathrm{Na}$ atualidade, o volume de informações geradas e consumidas vem aumentando aceleradamente, e estas deixam seu suporte físico tradicional para tornarem-se digitais. Neste novo contexto, a tecnologia da informação pode ser considerada uma das principais ferramentas a serem utilizadas para obtenção de ganhos de qualidade e produtividade, principalmente se considerarmos sua rapidez e confiabilidade.

Não basta, portanto, ter disponíveis as informações, e, em alguns casos, isto pode até dificultar ainda mais os resultados, assim como lembrou Murray GellMann (1997) ${ }^{32}$ :

"A explosão da informação, sobre qual muito se comenta e escreve, é também, em grande medida, a explosão da informação errada e

\footnotetext{
${ }^{32}$ GELL-MANN, Murray. Information versus knowledge and understanding. 1997.
} 
mal organizada (...) A revolução digital apenas agravou os problemas".

É preciso, portanto, que as informações além de disponibilizadas, estejam organizadas e acessíveis de forma rápida e eficiente.

O segredo está em recuperar a informação, e não apenas guardá-la.

Conforme Bayma [200?] ${ }^{33}$ os avanços tecnológicos fazem do formato de fornecimento e uso da tecnologia os dois aspectos de distribuição diretamente relacionados às mudanças, surgindo novas opções de distribuição continuamente. Face à grande quantidade de formatos disponíveis atualmente, se torna difícil o processo de tomada de decisões sobre o formato de distribuição, implicando, ainda, que algumas formas e mecanismos de fornecimento possam ser adequados e outros não.

As novas tecnologias da informação e comunicação viabilizam essa pluralidade de serviços e produtos e a tendência está em bases de dados que cada vez mais conviverão com textos na íntegra (full-text) e não apenas com informações referenciais. Os recursos para o tratamento e disseminação de documentos multimídia, também serão a prática e não a exceção, o que muda significativamente a forma de tratar esses conteúdos informacionais.

Uma vez que as mudanças tecnológicas geram transições e transformações nas atividades e tarefas em contexto sócio-cultural, é preciso acompanhar as alterações da atualidade, isto é, aprender constantemente, e providenciar novos rumos na gestão da informação, pois os fluxos de informação

\footnotetext{
${ }^{33}$ BAYMA, Maria de Fátima Castro. Enfoque de marketing na distribuição da revista PAB, como produto de informação. Revista de Biblioteconomia de Brasília, Brasília, v. 22, n. 1, [200?] Disponível em: <http://rbb.org.br/V23-24/N1/bayma.htm> Acesso em: 19 dez. 2005.
} 
são influenciados, principalmente, pelo uso da Internet e seus recursos. O que se percebe, é que a introdução das TIC's em diferentes contextos acontece em escala global.

Essas transformações enfrentadas no acelerado processo de mudança, principalmente centrados no uso intensivo das novas TIC's, estão transformando as redes de relações em todas organizações, círculos de convivência e indivíduos. Por mais isolado que um indivíduo pense estar, não fica totalmente isento de tal processo, pois todos estão entrelaçados, uns com mais envolvimentos, outros com menos, uns direta, outros indiretamente.

Entretanto, convém lembrar que a literatura sobre impactos das TIC's na sociedade, de uma maneira geral e nas mais diversas instâncias, apresenta alguns equívocos.

Nesse sentido, Ramos $(2003)^{34}$, destaca como exemplo a contemporaneidade do tempo, ou seja, a utopia de que todas as mudanças acontecerão ao mesmo tempo. A sociedade integrada em rede revoluciona a sociedade da informação, em termos de organização social. Porém, as barreiras à usabilidade e acessibilidade deixam de fora do mercado da informação parte da sociedade, os "excluídos digitais".

\footnotetext{
${ }^{34}$ RAMOS, Magda Camargo Lange. A utopia dos bits: impacto das tecnologias de informação na interação bibliotecário/usuário (graduação) da Biblioteca Universitária da Universidade Federal de Santa Catarina. 2003. Dissertação (Mestrado em Engenharia de Produção) - Programa de Pósgraduação em Engenharia de Produção, Universidade Federal de Santa Catarina, Florianópolis, 2003. p.138.
} 
Meadows (1999) ${ }^{35}$ também já antevia uma divisão informacional (ricos e pobres de informação) entre pesquisadores de instituições nos países desenvolvidos e em desenvolvimento que têm bom acesso à Internet e aqueles de Instituições que não o têm, tendo como principal causa à falta de infra-estrutura de comunicação.

Sendo assim, a questão da recuperação da informação digitalizada apresenta-se como o maior entrave atualmente no que tange a sistemática de busca informacional por parte dos usuários, ou seja, a acessibilidade. $O$ ' $x$ ' da questão está em conseguir acessar informações qualitativas em um universo heterogêneo e com uma mescla infinita de arquivos digitais, daí a necessidade e importância em conhecer tecnologias de digitalização de documentos, o que, conseqüentemente, implica em escolhas difíceis, com um entendimento amplo dos diversos formatos, seus recursos, ferramentas e tipos de documentos.

\footnotetext{
35 MEADOWS, A. J. A comunicação científica. Tradução de Antônio Agenor Briquet de Lemos. Brasília: Briquet de Lemos/Livros, 1999. p.159.
} 


\title{
5. METODOLOGIA DA PESQUISA EM TURISMO
}

\begin{abstract}
"(...) o turismo é um fenômeno extremamente complexo e os temas e problemas não poderão ser resolvidos com os métodos convencionais de aquisição de conhecimentos. A experiência pode ser uma grande mestra, mas o campo do turismo demanda atualmente técnicas sofisticadas de investigação que provam ser efetivas em outros âmbitos".

(GUNN, Clare A. A perspective on the purpose and nature of tourism research methods.).
\end{abstract}

O acesso a acervos bibliográficos para atender à demanda de informações especializadas em determinados campos do conhecimento é tarefa árdua e complexa, pois as opções disponibilizadas são extensas e variadas.

No que se refere ao fenômeno turístico, este, apesar da grande gama de estudos realizados, ainda carece de estudos direcionados à metodologia da pesquisa científica.

O mapeamento dos métodos nos leva a pensar que não há conhecimento fora de uma sistematização metodológica nem que possa estar distanciado de marcos reconhecíveis. O que importa afirmar que todo conhecimento é relativo, ou seja, não se caminha metodicamente sem que antes haja uma trilha, um percurso. Esta idéia conflita, todavia, com a experiência humana, pois a revelação do conhecimento pode dar-se tanto no desbravamento de novos espaços nos campos do saber como durante ou no final do percurso.

Conhecer sugere um processo em que, pelo trabalho das formas de percepção, a mente humana se propõe chegar a um objetivo que, supostamente, vai satisfazer a vontade que a anima. 
O método é o caminho a ser trilhado pelo pesquisador na busca de conhecimento, assim, o significado da palavra metodologia, quer dizer: viagem que se realiza em busca de um objetivo específico.

Tendo origem no verbete grego méthodos, metodologia traduz a idéia de ordenação, seqüência, arte, estudo, técnica, processo. O Novo Aurélio acentua três significados principais:

1. "arte de dirigir o espírito na investigação da verdade";

2. na Filosofia: "estudo dos métodos e, especialmente,dos métodos das Ciências";

3. na Literatura como: "um conjunto de técnicas e processos utilizados para ultrapassar a subjetividade do autor e atingir a obra literária".

O método oferece, portanto, a orientação geral para se chegar a um fim determinado, já a forma de aplicação do método refere-se a técnica, ou seja, como fazer.

De acordo com a Organização Mundial de Turismo a metodologia turística refere-se ao "conjunto de métodos empíricos experimentais, seus procedimentos, técnicas e táticas para ter um conhecimento científico dos fatos turísticos".

E é isso que se pretende com este estudo: descrever o caminho pelo qual o pesquisador da área de turismo vai precisar percorrer e fornecer indicações técnicas de como fazer para alcançar o conhecimento que almeja.

Para tanto, é extremamente importante que os pesquisadores na área de turismo tenham em mãos informações correntes atualizadas, capazes de reduzirem suas incertezas no momento da busca informacional, auxiliando-os nas tomadas de decisões. Suas necessidades informacionais não dizem respeito apenas aos processos tecnológicos e suas inovações, mas, também, a todo o 
desenvolvimento científico da área. Por isso, quando se analisa o fenômeno turístico atualmente, não se pode fazê-lo sem levar em consideração o contexto cultural e tecnológico em que se encontra inserido.

Como conseqüência do aumento da área de atuação do turismo, e o aparecimento de melhores tecnologias de informação e ferramentas de gerenciamento, novas atividades têm surgido, gerando assim, novas oportunidades de trabalho e pesquisa.

Em contrapartida o estudo e a pesquisa dessa área caminham lentamente no sentido de constituir um constructo, uma estrutura teórica consolidada, talvez pela forma fragmentada e pela segmentação com que é desenvolvido o turismo no Brasil, ou mesmo pela maneira que as pesquisas e estudos são conduzidos, sem confronto ou sistematização das pesquisas, resultando em esforços e estudos individuais.

De acordo com Dencker (1998) ${ }^{36}$ :

"Muitas são as disciplinas que tratam da questão do turismo e temos que admitir que ainda hoje o turismo não constitui um corpo de conhecimento independente, com dinâmica própria, mas está sujeito à influência de diferentes paradigmas, o que prejudica a formação de um corpo teórico específico[...]".

Em consonância com Dencker, Moesch (2002) ${ }^{37}$, também considera que o turismo moderno, tanto como fenômeno social, econômico e cultural reduz-se a um apanhado de informações relativas à sistemática operacional acerca do setor produtivo, sendo que a produção do saber turístico, especificamente no Brasil,

${ }^{36}$ DENCKER, Ada de Freitas Maneti. Métodos e técnicas de pesquisa em turismo. São Paulo: Futura, 1998. p.28.

${ }^{37}$ MOESCH, Marutschka Martini. A produção do saber turístico. 2. ed. São Paulo: Contexto, 2002. p.11. 
baseia-se essencialmente em iniciativas no setor privado e empresarial e muito pouco no meio acadêmico.

Assim, a formação de seu campo teórico é ainda carente em relação à construção racional e sistematizada de conhecimentos por meio da pesquisa científica e a maior dificuldade para o turismo é a de formar uma concepção epistemológica em contrapartida ao caráter profissionalizante gerado pelas exigências mercadológicas em que se transformou este saber. Só uma abordagem mais complexa, onde haja não só a preocupação com a informação operacional do mercado, mas também com o conhecimento científico propriamente dito que possibilite a análise e o desenvolvimento da capacidade crítica do pesquisador, ou seja, a técnica associada ao conhecimento, assim, como a teoria associada à prática, constituem-se em pilares fundamentais na formação holística do pesquisador em turismo.

Portanto, um dos desafios que hoje se apresentam para o Turismo é o de desenvolver capacidade de refletir e teorizar sobre suas práticas de forma a construir conhecimentos teóricos sólidos. O caminho da pesquisa científica tem sido o mais comum para a construção de teorias, por isso, uma das preocupações da área se expressa na busca do entendimento de suas fontes informacionais.

Sendo assim, a consolidação de um corpo teórico com bases epistemológicas (considerando a teoria, a lógica e o conhecimento) na área de turismo é imprescindível ao se fazer pesquisa científica. 


\title{
5.1 A Natureza Multidisciplinar do Turismo
}

\begin{abstract}
"Turismo é um universo personalizado de megas e diminutas dimensões, onde o inovador busca realizar um pouco diante dessa infinitude, jamais vislumbra o fim da espiral especulativa de suas reflexões, e recomeça sempre uma nova viagem quando sente a transformação do universo em seu próprio ser".

(BENI, 2002)
\end{abstract}

Durante décadas, os cientistas de outras áreas e pesquisadores em Turismo tentaram estabelecer um núcleo de pesquisas na área de turismo para assim definir suas fronteiras com outras disciplinas.

A busca de identidade levou a área de Turismo a várias tentativas de fundirse teoricamente com outros campos, de forma a ocupar posição científica.

Dencker (1998) sugere que, atualmente, a tendência em várias áreas do conhecimento, é a de se adotar uma abordagem interdisciplinar e multidisciplinar, de modo a alcançar a prática transdiciplinar, definindo a transdiciplinaridade como "a integração das relações interdisciplinares de maneira global", até que haja o desaparecimento dos limites fronteiriços entre as disciplinas.

"O ideal seria o mais elevado nível de integração educacional, a
transdiciplinaridade, ou seja, algo além das disciplinas em si. Os
programas interdisciplinares iniciam-se com as disciplinas, ao passo que
a transdiciplinaridade tem como ponto de partida um desfio ou problema
e, pelo processo de solução de problemas, auxiliado por diversos campos
de conhecimento, procura chegar a uma solução ou resolução viável".

Mas temos que admitir que o turismo, ainda hoje, não se constitui em um corpo de conhecimentos independentes, com dinâmica própria enquanto disciplina, mas sim como um objeto de estudo pertencente a várias disciplinas que repercute e se relaciona com diversas áreas do conhecimento, como a

\footnotetext{
${ }^{38}$ TRIGO, Luiz Gonzaga Godoi. A sociedade pós-industrial e o profissional em turismo. 5. ed. São Paulo: Papirus, 1998. p.159.
} 
antropologia, geografia, sociologia, história, administração, economia e muitas outras.

O estudo das fontes informacionais que nos conduzem ao conhecimento científico no âmbito do turismo, nos fazem perceber que em decorrência das particularidades expostas acima, este é um trabalho de natureza essencialmente multi ou interdisciplinar, uma vez que o turismo está inserido como objeto de estudo em diversas disciplinas, além de estar sujeito à influência de diferentes paradigmas.

Como já mencionou Sobrinho $(2004)^{39}$, o turismo não nasceu de uma teoria, mas de uma realidade histórica de evolução das técnicas que foi configurando-se sob o impacto de descobertas de diversos campos do conhecimento. Daí a gênese multidisciplinar do turismo e a diversidade de enfoques dentro do estudo do turismo.

Uma vez configurado o campo de atuação do turismo como complexo e multidimensional - as interligações de cada segmento espalham-se em muitas direções e, usualmente, cada assunto é uma síntese de vários segmentos múltiplos ligados -, podemos entender porque esta multidimensionalidade do turismo, conseqüentemente, acaba repercutindo na dificuldade com que os pesquisadores desta área se deparam no momento de selecionar e recuperar as fontes de informação mais adequadas.

39 SOBRINHO, Fernando L. A. Lugares, olhares e imagens: uma breve discussão sobre o planejamento turístico. Revista Múltipla, Ano IX, n. 16, junho, 2004. p. 71. 
Segundo Rejowski $(1997)^{40}$ não se tem um quadro geral de métodos e técnicas utilizadas nas pesquisas turísticas. Há uma infinidade de procedimentos metodológicos que variam conforme a disciplina na qual o estudo se insere, ou seja, a pesquisa em turismo recebe influência dos métodos de pesquisa já consagrados, uma vez que é uma área multidisciplinar. Assim, a pesquisa na área de turismo pode englobar várias outras ciências como a economia, a geografia, a sociologia e a administração entre outras. Desta forma, utiliza-se dos métodos de pesquisa advindos destas áreas do conhecimento, conforme ilustra a figura a seguir.

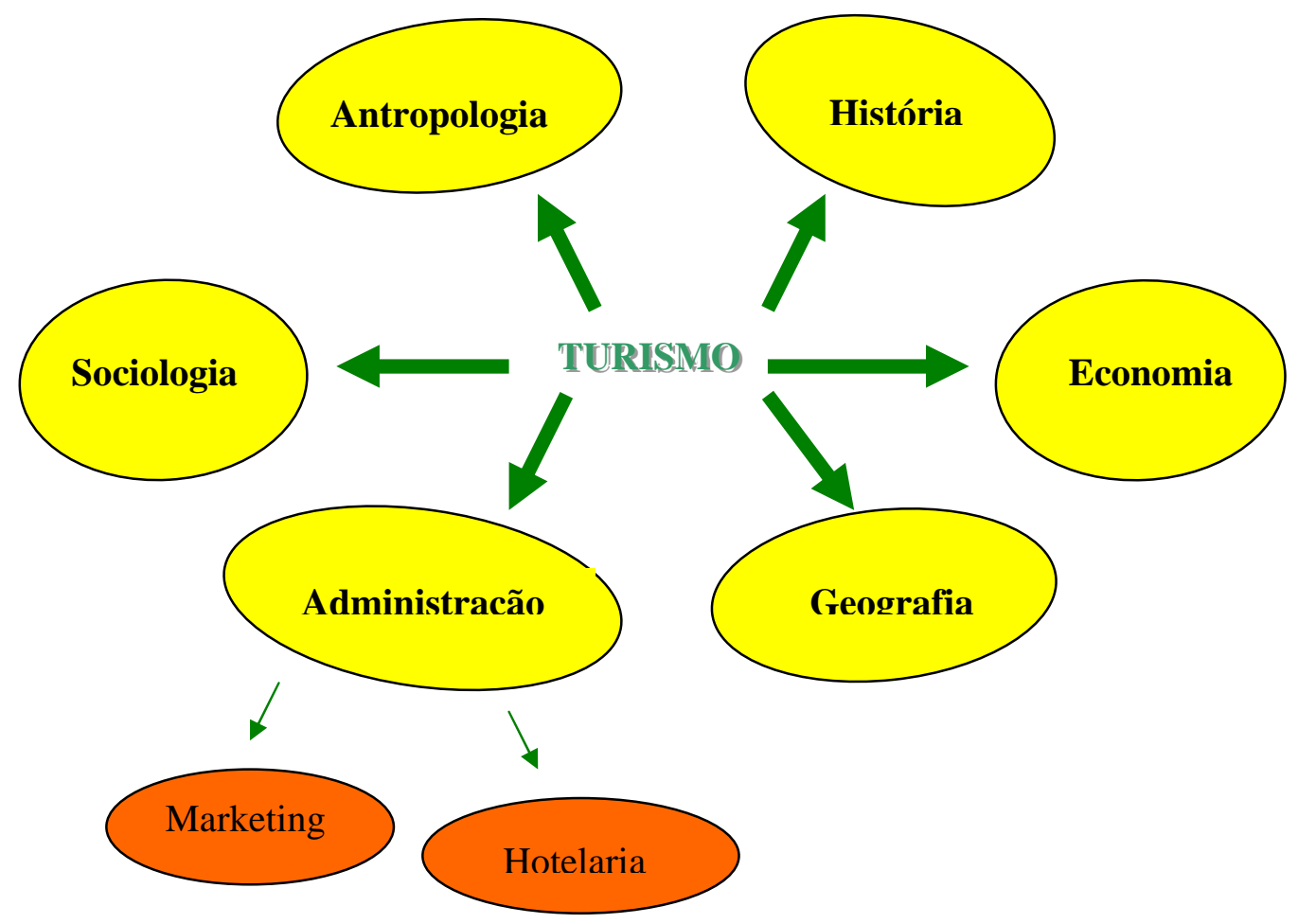

Fig. 6. A multidisciplinaridade da pesquisa em Turismo.

40 REJOWSKI, Mirian. Turismo e pesquisa científica: pensamento internacional x situação brasileira. 7. ed. Campinas: Papirus, 2003. p. 11. 


\title{
6. FONTES DE INFORMAÇÃO
}

\begin{abstract}
"Está implícito que a fonte última é imensurável, fora do alcance de nosso conhecimento."

(DAVID BOHM)
\end{abstract}

\subsection{Evolução dos Suportes de Informação}

O aparecimento do livro trouxe para a humanidade o instrumento capaz de consolidar os conhecimentos adquiridos através dos séculos, tornando-se o veículo de comunicação predominante.

No decorrer dos séculos, como observado por Chartier $(1994)^{41}$, o ato e estilo de leitura passaram por várias modalidades, proporcionando ao livro status diferenciado e, na segunda metade do século XVIII, a leitura extensiva, que caracterizaram a época, proporcionou o crescimento da produção, a multiplicação e a modificação dos formatos. Essas modificações, adotadas ainda até o presente momento, possibilitaram ao produtor e leitor da informação uma associação de formatos e gêneros, categorias de discursos e enorme variedade de tipos de material informacional, sendo que as funções diferenciadas e essenciais proporcionam a identificação e localização dos textos produzidos e armazenados.

\footnotetext{
${ }^{41}$ CHARTIER, Roger. Do códice ao monitor : a trajetória do livro. Estudos Avaçados, IEA/USP, v.8, n. 21, p.185-199, 1994.
} 


\title{
6.1.2 Livro Eletrônico
}

\begin{abstract}
"Apenas preservando a inteligência da cultura do códex poderemos gozar a felicidade extravagante prometida pela tela eletrônica".
\end{abstract}

(CHARTIER, 1994)

Com o desenvolvimento das TIC's, estas foram sendo acopladas aos antigos suportes de informação de forma a forneceram condições de se aplicarem novos "invólucros" à informação e que disponibilizassem maior capacidade de armazenagem e formas de acesso àqueles já tradicionalmente conhecidos.

Atualmente, segundo Chartier (1994):

"O livro já não exerce o poder de que dispôs antigamente, já não é o mestre de nossos raciocínios e sentimentos em face dos novos meios de informação e comunicação de que doravante dispomos".

Cada vez mais a informação está disponível na forma eletrônica, e existem várias classes de instrumentos para usá-las. A revolução do nosso presente é mais que a de Gutenberg, pois ela não modifica apenas a técnica de reprodução do texto, mas também as próprias estruturas e formas do livro impresso.

Nesse momento, o computador está sendo mais empregado como um intermediário para a recuperação de documentos impressos, mas gradualmente está sendo utilizado também para a produção dos próprios documentos primários.

Como destacou Chartier (1994), o livro eletrônico, afetará tanto a condição do texto impresso, como também a forma de leitura, criando novas relações com o escrito. Ler em um monitor não é o mesmo que ler um livro impresso. A forma eletrônica modifica a materialidade do livro pela imaterialidade sem lugar próprio. Interfere também nas relações de contigüidades estabelecidas no objeto impresso, 
opondo-se à livre composição de fragmentos e à navegabilidade por "arquipélagos textuais" sem limites. Esse "novo" livro, disponível atualmente, representa provavelmente o novo instrumento de transmissão do patrimônio escrito.

\subsubsection{Biblioteca Eletrônica ou Digital}

Paralelamente às modificações do suporte da informação, convém lembrar os aspectos quanto à organização e o armazenamento desta. O ritmo acelerado da produção do conhecimento e as transformações da sociedade exigiram que as bibliotecas implantassem infra-estrutura compatível com a demanda crescente, incorporando novos processos que proporcionassem o acesso mais rápido à informação bibliográfica.

Pode-se verificar que a biblioteca eletrônica ou digital ${ }^{42}$ proporciona ao usuário um acesso muito mais amplo e ágil às informações mundialmente disponíveis. Sendo assim, as instituições responsáveis pela gestão da informação se encontram exatamente no momento de refletir sobre os conceitos que esses produtos atualmente já disponíveis, e os novos que virão, estarão estabelecendo no novo contexto que se apresenta.

\footnotetext{
${ }^{42}$ Verificar no glossário a diferença entre biblioteca digital e biblioteca virtual.
} 


\subsection{Tipos de Fontes}

Esquemas de estruturação e classificação referentes aos tipos de materiais bibliográficos se baseiam no fluxo da informação, ou seja, estes materiais são classificados de acordo com o lugar e função que ocupam no fluxo de informação.

Este é um conceito que representa o caminho percorrido pela pesquisa, desde que nasce uma idéia na mente do pesquisador, passando pelo ápice que é a publicação formal dos resultados, e continua até que essa informação publicada na forma de livro ou artigo científico possa ser recuperada na literatura secundária ou apareça como citações em outros trabalhos, sendo que durante este processo, a informação é veiculada por meios e canais diversos.

Os canais de informação foram classificados, segundo Meadows ${ }^{43}$ (1974), como canais informais ou canais formais.

Nos canais informais a informação veiculada é recente e destina-se a um público restrito, tendo, portanto, o acesso limitado e sendo o próprio pesquisador quem o escolhe. As informações veiculadas nem sempre são armazenadas, sendo mais difícil de recuperá-las. Exemplos destes canais são os relatórios de pesquisa, os textos apresentados em seminários ou reuniões e mesmo anais de alguns simpósios.

Já os canais formais permitem um acesso mais amplo, de forma que as informações são facilmente coletadas e armazenadas. Ao contrário dos canais informais, é o destinatário da mensagem e não o pesquisador que o escolhe e

\footnotetext{
${ }^{43}$ MEADOWS, A. J. Communication in science. London: Butterworths, 1974.
} 
consulta. Enquanto os canais informais permitem um bom nível de interação com o pesquisador, os canais formais tradicionais normalmente não prevêem isso.

Da mesma forma, os documentos ou fontes produzidas ao longo do processo de pesquisa costumam ser classificadas como primárias, secundárias e terciárias.

Fontes primárias são normalmente aquelas produzidas com a interferência direta do autor da pesquisa. Inclui os relatórios técnicos, trabalhos apresentados em congressos, teses e dissertações, patentes, normas técnicas eo artigo científico.

Segundo Grogan (1992) ${ }^{44}$, as fontes primárias, por sua natureza, são dispersas e desorganizadas do ponto de vista da produção, divulgação e controle, sendo por essas razões, difíceis de serem identificadas e localizadas. Esse fato levou ao aparecimento das fontes secundárias, que têm justamente a função de facilitar o uso da informação dispersa nas fontes primárias.

As fontes secundárias apresentam a informação filtrada e organizada de acordo com um arranjo definido, dependendo de sua finalidade. São representadas, por exemplo, pelas enciclopédias, dicionários, manuais, tabelas, revisões de literatura, tratados, livros-texto, anuários e outras.

As fontes terciárias são aquelas que têm a função de guiar o pesquisador para as fontes primárias e secundárias. São as bibliografias, os serviços de indexação e resumos, os catálogos coletivos online, os guias de literatura, os diretórios entre outras. Após a publicação do artigo relatando a pesquisa em

${ }^{44}$ GROGAN, D. Science and technology: an introduction to the literature. 2. ed. Londosn: C. Bingley, 1992. p. 14-19. 
periódico científico, são as fontes secundárias e terciárias que ocorrem no contínuo do fluxo informacional.

Apesar de toda a evolução tecnológica e mesmo por causa dela, a necessidade de se conhecer as fontes e saber identificá-las de forma a promover o acesso à informação pertinente tornou-se requisito fundamental para a condução de pesquisas atualmente. 


\title{
7. FONTES DE INFORMAÇÃO ELETRÔNICAS EM TURISMO
}

\begin{abstract}
"Interpretar a realidade, torná-la lógica, compreensível, significativa para o conjunto de indivíduos supõe o ato de fazer sentido ao mundo existente. É por seu intermédio que o ser humano compreende, analisa e interpreta todas as dimensões da realidade, captando e expressando essa totalidade de forma cada vez mais ampla e integral".
\end{abstract}

(MORRAN, 1994)

\subsection{Bases de Dados}

Em sentido lato, bases de dados referem-se ao modo como os dados são armazenados em computadores. Elas podem ser:

> Uma coleção de dados sobre as atividades de uma organização, que permite o controle dessas atividades;

> Uma coleção de dados disponíveis publicamente, mantidos num computador hospedeiro ou servidor acessível por meio de uma rede de telecomunicações ou em CD-ROM.

Em sentido mais formal, uma base de dados é uma coleção geral e integrada de dados junto com a descrição deles, gerenciada de forma a atender a diferentes necessidades de seus usuários.

Bases de dados externos podem ser acessadas por intermédio dos serviços de buscas em linha ou adquiridas em CD-ROM. Uma vez que as bases de dados são essenciais para a forma como os dados são armazenados e recuperados, é importante que se conheça os tipos de bases de dados que existem, os formatos- 
padrão de registros, que sejam encontrados, bem como os métodos de estruturação de bases de dados.

\subsubsection{Tipos de Bases de Dados}

Há três tipos principais de bases de dados: bibliográficas ou referenciais, de texto completo e fatuais.

As bases de dados bibliográficas ou referenciais, como o nome indica, contêm registros bibliográficos que permitem ao usuário localizar determinada publicação (um artigo de periódico, de jornal, newsletter, um livro, uma dissertação, um relatório de pesquisa, um trabalho publicado em anais de congresso ou outras). Além de dados bibliográficos como autor, título, local, data de publicação e outros, essas bases podem, também, fornecer o resumo dos documentos.

Atualmente, estão se tornando cada vez mais comuns as bases de dados em texto completo, que contêm o documento completo, e não apenas sua citação. Se a base não possui o texto completo (como é o caso das bases bibliográficas) e se o documento referenciado não estiver disponível localmente, o usuário necessitará utilizar serviços de empréstimo entre bibliotecas ou de comutação de documentos (como o Comut ${ }^{45}$ ) para obtê-lo.

É por isso que a tendência das bases mais modernas é incluir o texto completo, solucionando essa limitação. As primeiras versões de bases em texto completo reproduziam apenas a parte textual dos documentos, omitindo gráficos,

\footnotetext{
${ }^{45}$ Para mais informações sobre forma de acesso, consultar o glossário.
} 
tabelas ou figuras. Hoje, já é bastante comum que os artigos em texto completo venham em formato PDF, um tipo de arquivo que reproduz fielmente gráficos, tabelas ou fotos que façam parte do arquivo. Além da vantagem óbvia de acesso imediato à informação, as bases de texto completo costumam permitir a busca por palavras que apareçam em qualquer local do texto, mesmo que elas não representem o seu foco principal. Essa característica permite que se localize informação que, de outra forma, dificilmente seria recuperada. Outra vantagem das bases de texto completo é que muitas delas, como as bases de notícias, são atualizadas continuamente, ao longo do dia.

Já as bases de dados fatuais fornecem respostas a perguntas que não visam obter como resposta uma bibliografia. Muitas delas são numéricas. Podem conter, por exemplo, listas de empresas ou informação financeira, como índices de inflação, cotações de ações e de outros títulos mobiliários. As informações de bases numéricas podem, muitas vezes, ser descarregadas em um arquivo de computador, para manipulação pelo usuário por meio de programas de planilhas ou processadores de texto.

A diferença entre os três tipos de bases, geralmente, não é nítida. $\mathrm{Na}$ realidade, uma tendência significativa é que as bases de dados tenham características dos vários tipos mescladas. Por exemplo, algumas bases podem combinar informação bibliográfica com diretórios. Esse seria o caso de uma base de descrições de empresas que listasse também citações de artigos sobre as empresas. 


\subsubsection{Interfaces e Meios de Acesso}

As interfaces de busca oferecidas variam de sistema para sistema. As interfaces baseadas em comandos são destinadas a profissionais da informação, mas requerem treinamento e prática para que sejam dominadas e para que possam ser utilizadas eficientemente. Essas interfaces estão se tornando cada vez menos comuns. Algumas empresas (como, por exemplo, a OCLC ${ }^{46}$ ) têm eliminado essas interfaces completas em favor das interfaces, gráficas ou de menus, voltadas para usuários finais. Os sistemas para usuários finais são mais simples de serem utilizados, mas, freqüentemente, profissionais experientes preferem as antigas linguagens de comando por possibilitarem maior rapidez e flexibilidade nas buscas.

A maioria das bases de dados de informação para negócios são caras, embora existam algumas de baixo custo ou mesmo gratuitas, como aquelas criadas e disponibilizadas por órgãos do governo. Catálogos de bibliotecas, atualmente disponíveis para pesquisa via Internet, são gratuitos e podem ser de grande utilidade para o pesquisador. Com o advento da Web, as organizações produtoras dessas bases passaram a oferecê-las via rede, facilitando enormemente o acesso.

As bases podem ser armazenadas em meios magnéticos ou ópticos como discos, e acessadas local ou remotamente. Algumas dessas bases de dados conterão informações de acesso público, como resumos e índices, textos

\footnotetext{
${ }^{46}$ Ver lista de abreviaturas.
} 
completos de relatórios, enciclopédias e livros, enquanto outras serão compartilhadas no âmbito de uma instituição ou grupo de instituições.

Quanto às formas de acesso, as bases de dados podem estar disponíveis on-line, via Internet em CD-ROM ou em disquetes, sendo que cada sistema tem suas vantagens e peculiaridades.

Bases on-line são disponibilizadas via redes de computadores, outras que não a Internet. São atualizadas com maior freqüência e permitem a forma de acesso mais rápida. Entretanto, o custo de acesso costuma ser mais alto, por incluir o custo de telecomunicação.

O oferecimento via Internet tem a mesma vantagem de atualização freqüente e oferece custos menores de acesso remoto, mas as interfaces são, geralmente, simplificadas e talhadas para o usuário final, e não para o profissional, e o acesso pode ser demorado, em determinados horários.

O CD-ROM, por sua vez, oferece, em geral, interfaces simplificadas para o usuário final com uma variedade de alertas (prompts), mensagens de ajuda e instruções. Não implica qualquer custo de acesso, pois, uma vez adquirido, pode ser pesquisado quantas vezes for necessário, sem custo adicional. Tem a vantagem de ser um meio de alta capacidade de armazenamento, podendo conter 1.500 vezes os dados de um disquete, permitindo, assim, que o conteúdo retrospectivo de grandes bases seja disponibilizado localmente. Por outro lado, as bases em CD-ROM's são menos atualizadas que as disponibilizadas via rede, já que as versões atualizadas dos CD-ROM's chegam em períodos determinados (semanal, mensal, trimestral, semestral ou anual, por exemplo). Outra desvantagem do CD-ROM é a necessidade de investimento para disponibilização 
dos mesmos, em rede. Caso esse investimento não seja feito, cada disco poderá ser usado por apenas um usuário de cada vez.

Há também algumas bases que estão disponíveis em disquetes, contendo, necessariamente, arquivos menores. Os mais comuns são arquivos de dados econômicos, financeiros e demográficos.

Qualquer que seja o meio de acesso às bases, a falta de padrões dos softwares de busca utilizados acarretam muitas reclamações por parte dos usuários, que precisam aprender a usar uma multiplicidade de sistemas.

De qualquer forma, assim como foi demonstrado anteriormente, as bases de dados cobrem um amplo universo de informações selecionadas, organizadas e fornecidas em meio eletrônico, podendo, dessa forma, serem mais facilmente encontradas e acessadas que nas fontes impressas.

Utilizando-se das bases de dados, um pesquisador pode reunir, em poucos minutos, informações que, de outra forma, levariam dias para serem obtidas em fontes impressas ou entrando-se em contato com fontes pessoais ou organizacionais. Além disso, pode-se afirmar que a pesquisa em bases de dados permite descobrir dados que seriam impossíveis ou muito difíceis de conseguir em fontes impressas, devido à limitação de seus pontos de acesso e à impossibilidade da busca por palavras, no texto completo.

Entretanto, a existência de uma vasta quantidade de informação grátis na Internet trouxe questionamentos sobre os serviços comerciais de bases de dados, que são vistos como caros e difíceis de serem usados. Embora alguns vejam a gratuidade da Internet como uma ameaça à indústria de bases de dados, estes dois segmentos devem ser percebidos como fontes complementares de 
informação. Cada uma dessas modalidades de fontes eletrônicas de informação tem seus pontos fortes: a Internet não tem paralelo no que diz respeito à quantidade e variedade de informação grátis e às publicações cinzentas ${ }^{47}$, que envolvem não apenas a literatura efêmera que as bibliotecas tendem a não coletar, mas todo o segmento de publicações não oficiais ou quase oficiais, incluindo conversações em listas e grupos de discussão. Distingue-se ainda pela possibilidade da interatividade e pela facilidade de se estabelecerem contatos com fontes pessoais e organizacionais de informação.

Por outro lado, a informação na Internet pode ser de acesso demorado, é desorganizada e caótica e pode ter sua autoridade contestada, enquanto a informação em bases de dados pode ser cara, mas é pontual, precisa, confiável e pode ser obtida com mais rapidez.

Apesar da informação na Internet não substituir aquela contida nas bases de dados, seu advento como fonte alternativa de informação eletrônica em rede impactou as empresas on-line, que têm buscado as melhores formas de se inserirem no novo contexto, obtendo proveito dele.

\title{
7.2 Estratégias de Busca
}

\begin{abstract}
“Tal como noutros períodos de transição, difíceis de entender e de percorrer, é necessário voltar às coisas simples, à capacidade de formular perguntas simples, perguntas que, como Einstein costumava dizer, só uma criança pode fazer, mas que, depois de feitas, são capazes de trazer uma luz nova à nossa perplexidade".
\end{abstract}

(SANTOS, 2003)

\footnotetext{
${ }^{47}$ Representada pelos relatórios, trabalhos apresentados em congressos, palestras e artigos de periódicos entre outros. Ao conjunto dessas publicações denominamos literatura científica.
} 
Bates (1988) ${ }^{48}$ conceituou a estratégia de busca como o "estudo da teoria, princípios e prática de planejar e executar táticas e estratégias de busca" sendo que o planejamento e a execução de uma estratégia nada mais é que a "arte de escolher onde, quando e com que investigar cuidadosamente" a fonte de informação para alcançar objetivos específicos.

A escolha de onde buscar, identificando qual base de dados é a mais bem qualificada para atendimento das perguntas específicas do pesquisador, depende de uma série de fatores relacionados com a abrangência de assunto e período da base, dos tipos de documentos indexados, da linguagem de indexação, dos campos de busca disponibilizados em determinado banco de dados e outros.

Em um outro estudo sobre estratégias de busca, Bates $(1990)^{49}$, separou o processo de busca em bases de dados em duas partes: uma realizada por indivíduos e a outra pelo sistema de recuperação. Observou que o processo de busca efetuado por pessoas é constituído por diferentes movimentos, táticas, estratagemas e estratégias. Definindo o movimento como um pensamento ou ação que é parte do processo de busca, demonstrou que a tática é composta por um ou mais movimentos executados no mesmo processo. O estratagema seria constituído pelo uso de múltiplas táticas e/ou movimentos, e a estratégia seria o planejamento que conteria os movimentos, as táticas e os estratagemas para a completa busca da informação. Quanto ao processo de busca realizado pelo

\footnotetext{
48 BATES, Marcia J. How to use controlled vocabularies more effectively in online searching. Online, v. 12, n. 6, p. 45-56, nov. 1988.

49 . Where should the person stop and the information search interface start? Information Processing and Management, v. 26, n. 5, p. 575-591, 1990.
} 
sistema de recuperação, este seria composto entre outros pela linguagem de busca do sistema e pela estrutura de informação da base de dados.

Bates (1999) salienta ainda algumas dificuldades relacionadas com as habilidades de pesquisa em bases de dados e apresenta um breve roteiro com as qualidades necessárias para o pesquisador que planeja e executa a estratégia de busca.

Ojala $(1995)^{50}$ analisou os diversificados recursos de busca oferecidos pelos sistemas em linha que podem afetar a decisão do pesquisador na escolha do melhor sistema para a realização de uma busca de informação em uma determinada base de dados. Mencionou alguns fatores, como as variações no uso de operadores booleanos, o uso de operadores de proximidade, a quantidade de frases da estratégia de busca que podem ser operacionalizadas e outras.

Tenopir (2000) ${ }^{51}$ discute a importância do planejamento da estratégia de busca pelo intermediário, destacando a experiência prévia dos mesmos, com as correspondentes versões impressas das bases de dados. Relaciona ainda as fontes de informação que oferecem texto completo dos documentos, analisando também as tendências para os periódicos eletrônicos.

Cabe destacar que esses estudos realizados em plena era do acesso à informação por meios eletrônicos, em que os usuários navegam na Internet com desenvoltura, ainda revelam as dificuldades inerentes ao processo de recuperação da informação em bases de dados. Apesar dos intensivos programas de treinamento oferecidos pelos produtores das bases de dados, pelos próprios

\footnotetext{
50 OJALA, M. The rhythm of searching. Online, v. 20, n. 4, p. 52-54, July/Aug. 1996.

51 TENOPIR, C. Are you a super searcher? Library Journal, v. 125, n. 4, p. 36-38, 2000.
} 
sistemas de recuperação em linha, de toda a documentação existente sobre as características de cada base de dados e suas respectivas estruturas de informação, dos sistemas amigáveis que oferecem "menus" para guiar o usuário em cada etapa do processo de busca, das linguagens de busca com recursos especiais para se aproximarem cada vez mais do usuário inexperiente, o processo de busca continua apresentando um fator de dificuldade que ainda não foi minimizado pelas novas tecnologias disponíveis.

\title{
7.2.1 Técnicas de Estratégia de Busca
}

\begin{abstract}
"Oferecer informações básicas para o desenvolvimento das atividades de pesquisa com caráter científico, de forma a articular equilibradamente os fundamentos filosóficos, empíricos, epistemológicos e éticos com as orientações técnicas para o desenrolar da pesquisa, superando a visão tecnicista, muitas vezes predominante".

(PÁDUA, 2002)
\end{abstract}

No planejamento da estratégia de busca, algumas ações ou táticas precisam ser criteriosamente relacionadas, principalmente com a seleção de termos e/ou conceitos e com as restrições e/ou limites determinados pelo pesquisador entre outras questões.

Oldroyd \& Citroen $(1977)^{52}$ identificaram três grandes etapas para decisão no processo de planejamento da estratégia de busca:

1. Decisão sobre qual a melhor base de dados para um determinado tema;

2. Decisão referente à seleção dos termos de busca e sua adequação para a base a ser consultada;

52 OLDROYD, B. K; CITROEN, C. L. Study of strategies used in online searching. Online Review, v. 1, n. 4, p. 295-310, 1977. 
3. Decisão sobre a formulação lógica da estratégia.

Para a preparação da estratégia de busca, o pesquisador deve escrever um título sucinto, escrever uma pequena definição do problema, listar os termos ou palavras-chave mais apropriadas para o tópico de interesse e listar os termos que não são desejados.

A partir desses dados, o pesquisador poderá executar a busca de informação de uma forma relativamente simples. E, se vários dos maiores autores que publicam sobre o assunto solicitado puderem ser relacionados, então a busca será muito mais eficiente.

A seguir, são apresentadas orientações que podem ajudar o pesquisador a definir o problema, contribuindo, portanto, para acentuar a qualidade da busca.

Se o pesquisador se familiarizar com alguns dos instrumentos básicos de auxílio para a busca em seu campo, por exemplo, um thesaurus ${ }^{53}$, isto pode ajudar a definir o tópico e gerar uma lista das palavras-chave a serem usadas na estratégia de busca.

Após o pesquisador ter selecionado um tópico claro e descritores válidos, este se encontra preparado para formular uma estratégia de busca inicial (tentativa). A busca estará bem definida se o pesquisador for capaz de assegurar a recuperação de todas as citações para vários termos. Mas, tipicamente a informação mais complexa, aquela que requer a interseção de, pelo menos, dois

\footnotetext{
${ }^{53}$ Um thesaurus é uma linguagem artificial e controlada com uma coleção exaustiva de termos relativos a determinada área do conhecimento, alfabética e sistematicamente ordenados. Assemelha-se a um dicionário que registra uma lista de palavras que são associadas semanticamente a outras, apresentando geralmente sinônimos e, algumas vezes, antônimos. Um thesaurus é constituído por um conjunto de vários descritores (palavras-chave dos documentos). Cada um deles tem uma definição própria e a cada documento podem ser atribuídos vários descritores. Sendo um conjunto de palavras indexadas (vocabulário controlado), permitem que seja mais fácil uma pesquisa por assunto e a recuperação da informação.
} 
conjuntos de termos, é desejável. Neste caso, é preciso que o pesquisador agrupe termos similares em um só conjunto e, sucessivamente, até alcançar a resposta desejada.

Além disso, é fundamental que o pesquisador compreenda as propriedades básicas da teoria dos conjuntos tal como é usada nas estratégias de busca por computadores. O uso da interseção de mais de dois conjuntos de termos deve ser evitado, porque, embora os resultados possam ser bem precisos, eles são muito limitados e podem provocar uma possível exclusão de informações relevantes.

Nesta etapa da pesquisa, entra a questão da interdisciplinaridade. $\mathrm{O}$ pesquisador precisa conhecer sobre os campos de pesquisa correlatos e como usá-los para responder a questões que demandam buscas interdisciplinares. Freqüentemente o pesquisador não está familiarizado com os campos de pesquisa relacionados, cabe, portanto, ao especialista de uma unidade de informação ou biblioteca propor a expansão da busca para estes outros campos, aumentando, conseqüentemente, as possibilidades de documentos de interesse serem recuperados.

Nesta outra etapa, convêm eliminar os termos indesejados da pesquisa.Existem várias maneiras de se eliminarem termos indesejados. Se o pesquisador não está interessado em citações sobre um determinado conceito, deve eliminar do resultado final todas as citações que tiverem o termo citado. Mas existem problemas com este enfoque. Ocasionalmente, ambos os termos ocorrerão na mesma citação. Portanto é importante que o pesquisador examine minuciosamente a real necessidade de exclusão de termos afins com o tema pesquisado. Os termos indesejados só devem ser realmente excluídos do 
resultado da busca depois de se ver o impacto dessa exclusão no resultado total da busca. A decisão para excluir termos nem sempre é fácil e, visualmente, depende da especificação do tópico.

Finalmente, todos os parâmetros relevantes devem ser considerados para se determinarem os limites da busca. Quanto, em termos de recursos financeiros, pode ser gasto na busca? Deve a busca ser limitada nos anos mais recentes? Quais as bases de dados que provavelmente irão fornecer as mais relevantes citações? O pesquisador deve responder a todas estas questões antes da tomada de decisões para, posteriormente, realizar o planejamento da estratégia de busca.

Essas etapas estão baseadas na experiência adquirida por profissional e especialistas da área e são como um roteiro sugerido para uso, por usuários e/ou pesquisadores iniciantes nas buscas em bases de dados em CD-ROM ou em linha. Essas etapas podem ser categorizadas como pré-requisitos indispensáveis para o planejamento das estratégias de busca.

\subsection{FERRAMENTAS DE PESQUISA}

\subsubsection{Operadores Booleanos}

Os operadores lógicos mais comuns são usados para relacionar termos ou palavras e para alargar ou diminuir a extensão de sua pesquisa na montagem de uma expressão de busca informatizada.

Dependendo da Base de Dados, deverão ser grafados por sinais representativos, mas com o mesmo conceito. Por exemplo: * (and) + (or) ^^ (not). 
Verificar no help de cada Base de Dados as possíveis variações e os exemplos de uso. Algumas Bases usam, por exemplo, AND NOT, e não somente NOT. Há outros operadores muito importantes também, que poderão ser usados nas buscas informatizadas e são descritos no help de cada uma delas.

\section{AND (*)}

Usado para relacionar termos de busca, restringindo o resultado, pois TODAS as palavras precisam ocorrer NO MESMO documento para que ele seja mostrado.

Ex.: turismo AND rural AND Brasil

\section{OR (+)}

Usado para somar termos de busca, ampliando o resultado da pesquisa, pois se no documento ocorrer apenas uma das palavras (ou mais), ele será recuperado. Deverá ser usado entre termos sinônimos e correlatos, entre nomes científicos e populares de espécies de plantas e animais, etc., para que sejam recuperados documentos que tragam termos de uma forma ou outra.

Ex.: educacao OR pedagogia OR didatica OR ensino OR aprendizagem

\section{NOT (^)}

Usado para EXCLUIR documentos que tragam um conceito que não se queira recuperar.

Ex.: ecoturismo NOT turismo 


\subsubsection{Truncagem (\$) ou (*) Truncatura}

Usa-se o recurso da truncagem quando se deseja recuperar todas as terminações possíveis de um mesmo radical. Os sinais mais comumente usados para truncagem são: (\$) ou (*) ou (?)

Ver em cada Base de Dados, no help, qual é o sinal adotado. Deverá ser colocado logo após o radical do qual se deseja recuperar todas as derivações: Ex.: educa* recupera: educador, educacional, educação, educar.

\subsection{Manual de Pesquisa em Bases de Dados Bibliográficas}

Sintetizando de forma mais didática o exposto anteriormente, cada campo de dados é um campo de busca da base de dados, isto é, o seu conteúdo pode ser recuperado através de uma expressão de pesquisa montada em um dos formulários de pesquisa (básico, livre ou avançado), disponibilizados pela Base de Dados escolhida.

Vale enfatizar que o resultado de uma pesquisa é totalmente dependente da expressão de pesquisa montada pelo pesquisador. Para montar uma expressão de pesquisa correta é importante saber como os campos de dados estão organizados na base pesquisada. Estes campos não necessariamente são ou estão organizados da mesma forma nas bases de dados disponíveis para consulta, sendo a falta de padronização das bases, um dos fatores que mais dificultam o processo de recuperação da informação pelos pesquisadores. 
Pois bem, os principais campos de busca são:

\author{
Autor \\ Descritor de assunto \\ Limites de assunto \\ Palavras \\ Palavras do título \\ Revista \\ Ano de Publicação \\ Idioma
}

\title{
7.4.1.Dicas de Pesquisa
}

Antes de começar a busca, faça a seguinte pergunta:

1. Que informação estou procurando? Considere indicar isto na escrita em duas ou três expressões.

2. Liste palavras-chave em português e em inglês que se relacionem aos termos de busca;

3. Se há interesse no trabalho de um autor específico, este pode ser um bom referencial para começar a busca. Podem ser utilizados artigos escritos por este autor para levantar outros originais relevantes;

4. Depois de encontrar um par de originais relevantes, considere usar os descritores associados ao registro para encontrar registros similares; 
5. Necessitando de informações adicionais, monte estratégias de busca utilizando corretamente os operadores booleanos e escolhendo as Bases de Dados mais pertinentes.

7.4.2.Exemplos de Estratégias de Busca usando mais de um Operador Booleano e vários Termos de Busca

$>$ (termo1 OR termo2 OR termo3 OR termo4) AND (termo1 OR termo2 OR termo3)

$>$ (termo1 AND termo2 AND termo3) OR (termo1 AND termo2 AND termo3)

termo1 AND (termo1 OR termo2 OR termo3)

termo1 NOT (termo1 OR termo2 OR termo3)

\subsection{Principais Bases de Dados e Bibliotecas Digitais no Brasil}

\section{$>\quad$ PORTAL PERIÓDICOS CAPES}

Acesso aos textos completos de artigos de cerca de 8104 revistas, nacionais e estrangeiras. Inclui também indicações de importantes fontes de informação. O acesso ao Portal é gratuito e permitido exclusivamente através das estações de trabalho instaladas nas dependências das Instituições de pesquisa ou em locais a elas associados. Disponível em: <http://www.periodicos.capes.gov.br> 


\section{$>\quad$ CATÁLOGO COLETIVO NACIONAL DE PUBLICAÇÕES SERIADAS}

CCN. Coordenado pelo IBICT, é uma rede cooperativa de unidades de informação de instituições localizadas no Brasil. Possibilita o acesso a publicações periódicas científicas e técnicas e reúne informações de centenas de catálogos produzidos pelas principais bibliotecas do país, em um único catálogo nacional de acesso público. Disponível em: <http://www.ibict.br>

$>\quad$ ERIC

Fonte de informação na área da Educação contém mais de 950.000 citações e resumos de periódicos científicos de pesquisa e prática em Educação. Disponível em: <http://www.eric.ed.gov/>

BIBLIOGRAFIA BRASILEIRA DE EDUCAÇÃO E BIBLIOTECA VIRTUAL DE EDUCAÇÃO

INEP - Instituto Nacional de Estudos e Pesquisas Educacionais. Disponível em: <http://www.inep.gov.br/>

$>\quad$ SCIENTIFIC ELECTRONIC LIBRARY ONLINE - SCIELO

Biblioteca digital com coleção de periódicos brasileiros em texto completo. Organiza e publica textos completos de revistas brasileiras na Web, assim como, produz e divulga indicadores de uso e impacto desses periódicos. Disponível em: $<$ <ttp://www.scielo.br> 


\section{$>\quad$ PORTAL PARA INFORMAÇÃO CIENTÍFICA E TECNOLÓGICA - PROSSIGA}

Disponibilizada a partir de 2003. Reúne desde informações sobre geradores de conhecimento (pesquisa e pós-graduação), ensino e treinamento, inclusive à distância, assim como programas, projetos e legislação relevantes principalmente para formuladores de políticas. O conteúdo do site está organizado em categorias como "Política de Informação Científica e Tecnológica", "Gestão e Operação de ICT" e "Produção Científica em Tecnologias da Informação". Destaca ainda eventos na área de ICT e notícias de interesse para profissionais do setor. Disponível em: < http://www.prossiga.br/informacaoct>

\section{BASES DE DADOS BRASILEIRAS NA INTERNET - PROSSIGA}

Portal lançado pelo Prossiga em junho de 2002. O conteúdo do site reúne as principais fontes de referência para $C \& T$, disponíveis na Internet. São informações sobre associações e sociedades científicas, instituições de pesquisa e de ensino superior, institutos tecnológicos, periódicos, museus, bases de dados, programas de pós-graduação, etc. O site permite a busca por assunto ou palavras-chave, e traz ainda lista de produtores de bases de dados. Disponível em:<http://www.prossiga.br/basesdedados/> $<$ http://www.prossiga.br/portaldereferencia/>

\section{BIBLIOTECAS VIRTUAIS DO PROSSIGA}

Disponível em:<http://www.prossiga.br/bvtematicas/> 


\section{PROGRAMA GMID-GLOBAL MARKET INFORMATION DATABASE}

Cobre as áreas de Economia, Administração, Turismo, Comércio Exterior, Relações Internacionais, Comunicação Social, Propaganda e Markentig, entre outras. Disponibiliza serviços de pesquisa que contêm estudos econômicos, monitoramento dinamicamente atualizado das economias de 205 países sob temas como investimento, comércio exterior, meio ambiente, consumo, recursos energéticos, mercado de consumo, com acesso simultâneo via Internet, permitindo análises comparativas extraídas em formatos Excel, Gráficos e Word. Para acessá-la é preciso fazer assinatura. Disponível em: $<$ www.gmid.euromonitor.com>

\section{BIBLIOTECA VIRTUAL EM SAÚDE - BVS}

O portal de pesquisa bibliográfica da BVS reúne 14 bases de dados bibliográficas em ciências da saúde, com acesso livre e gratuito. Reúne informações relativas ao conhecimento científico e técnico em saúde, registrado, organizado e armazenado em formato eletrônico. Mantida pela BIREME, tem como um dos produtos principais a LILACS (Literatura Latino Americana e do Caribe em Ciências da Saúde), base de dados contendo referências bibliográficas de artigos de periódicos, livros e teses existentes no acervo das bibliotecas que integram a Rede Latino Americana em Ciências da Saúde. Ver também MEDLINE e outras bases em áreas especializadas. Disponível em: <http://www.bireme.br>

\section{BASES BIBLIOGRÁFICAS (PORTAL DE REFERÊNCIA)}

Lista algumas das principais bases bibliográficas da literatura científica brasileira. Disponível em:<http://www.ndc.uff.br/sir/bases_biblio.htm> 


\section{MAPA DA MINA}

Site mantido pela Biblioteca da Unesp com lista de bases de dados e outros recursos eletrônicos. Disponível em:

<http://www.rc.unesp.br/biblioteca/mapadamina.html>

\section{BIBLIOTECA DIGITAL DE TESES E DISSERTAÇÕES DO IBICT}

Coordenada pelo IBICT, a BDTD reúne em uma base de dados única cerca de 100 mil registros de teses e dissertações produzidas por brasileiros no país e exterior. Conta com uma rede de 17 instituições cooperantes cujas 138 bibliotecas mantêm disponível para cópia, por meio do COMUT, ou empréstimo os exemplares das teses e dissertações. O programa visa também estimular 0 registro e a publicação de teses e dissertações em meio eletrônico. Disponível em: $<$ http://www.ibict.br/bdtd/inicio.htm>

\section{$>\quad$ TESES E DISSERTAÇÕES BRASILEIRAS}

A Capes abriu, em junho de 2002, o acesso para consulta de 185 mil teses e dissertações, apresentadas nos programas de pós-graduação do país, entre 1987 e 2001. Está disponível uma ferramenta de busca que permite a pesquisa por autor, título, palavra chave e palavras constantes do resumo. As informações constantes desta base de dados são fornecidas diretamente à CAPES pelos programas de pós-graduação mantidos por universidades e instituições de pesquisa brasileiras e são de sua inteira responsabilidade. Disponível em: <http://www.capes.gov.br/Scripts/index.idc?pagina=/servicos/indicadores/TesesDis sertacoes.htm> 


\section{$>$ BIBLIOTECA DIGITAL DE TESES DE DISSERTAÇÕES DA USP}

Disponibilizada em julho de 2001, possui inicialmente Teses e Dissertações realizadas a partir de julho de 2001. As anteriores serão digitalizadas futuramente. A produção anual média oriunda dos mestrados e doutorados, na USP, é de 4.000 defesas. A biblioteca digital de teses e dissertações da USP faz parte do "Saber Portal do Conhecimento" que visa colocar à disposição da comunidade acadêmica os recursos da universidade. A nova biblioteca digital está associada a uma iniciativa global ligada à Unesco (Organização das Nações Unidas pela Educação, Ciência e Cultura), a "Networked Digital Library of Theses and Dissertations" (Biblioteca Digital Reticular de Teses e Dissertações), com mais de 100 Universidades da Europa e dos Estados Unidos cadastradas. A USP é a primeira Universidade da América do Sul a se filiar à NDLTD. Disponível em: $<$ http://www.saber.usp.br>

\section{$>$ BIBLIOTECA DIGITAL DA UNICAMP}

Podem ser encontradas teses e dissertações nos seguintes tópicos: Artes, Biologia, Economia, Educação, Educação Física, Engenharia Agrícola, Engenharia Civil, Engenharia Elétrica e de Computação, Engenharia Mecânica, Engenharia Química, Engenharia de Alimentos, Estudos da Linguagem, Filosofia e Ciências Humana, Física, Geociências, Instituto de Computação, Matemática Estatística e Computação Científica, Medicina, Odontologia, Química. Disponível em: <http://www.rau-tu.unicamp.br/nou-rau/sbu/>

\section{UMI PROQUEST DIGITAL DISSERTATIONS}

DISSERTATION ABSTRACTS - DAI. Fonte de informação sobre teses apresentadas a partir de 1997, em cerca de 1000 universidades, principalmente americanas e européias, nas diversas áreas do conhecimento, incluindo resumos 
das dissertações e teses. Pode-se solicitar a cópia de tese via Portal. O site permite a busca e acesso livre aos últimos dois anos de citações e resumos na base de dados DISSERTATION ABSTRACTS. Para pesquisar na base completa - com mais de 1,6 milhões de títulos, é necessário ter uma assinatura. Disponível em: <http://wwwlib.umi.com/dissertations/gateway>

\section{UNIVERSIA}

Portal introduzido no Brasil em março/2002, voltado para a comunidade acadêmica ibero-americana e que já reúne cerca de 400 universidades na Argentina, Chile, Espanha, México, Peru, Porto Rico e Venezuela. Lançado em julho de 2000, na Espanha, seu conteúdo inclui teses acadêmicas. Disponível em: $<$ http://www.universia.net>

\subsection{Uso Apropriado da Informação Eletrônica}

O uso apropriado das publicações ou informações eletrônicas é definido como a prática socialmente aceita e legalmente permitida do livre uso da informação sob propriedade intelectual ou industrial para fins de educação, ensino, pesquisa e avanço do conhecimento científico e tecnológico. Neste sentido, fica garantido, de um lado, o livre fluxo da informação no processo de comunicação acadêmica e, de outro, o respeito aos direitos autorais estabelecidos. 


\subsubsection{Lei dos Direitos Autorais}

A questão dos direitos autorais em meio eletrônico tem um aspecto importante para o acesso à informação que diz respeito aos processos de reprodução, distribuição e uso de materiais impressos e eletrônicos, inclusive base de dados, como obras de criação intelectual brasileira.

Os direitos autorais no Brasil são regidos pela Lei 9.610, de 19 de fevereiro de 1998 que altera, atualiza e consolida a legislação sobre direitos autorais.

Os 110 artigos da Lei se aplicam a todo "tipo de obra intelectual, expressa por qualquer meio ou fixada em qualquer suporte tangível ou intangível, conhecido ou que se invente no futuro".

Alguns dispositivos da Lei são particularmente importantes para o desenvolvimento de serviços compartilhados e de acesso à informação, tanto impressa quanto eletrônica, como por exemplo:

O artigo 29 determina que a reprodução ${ }^{54}$ total ou parcial e a distribuição ${ }^{55}$ mediante cabo, fibra ótica, satélite, ondas ou quaisquer outro sistema que permita ao usuário realizar a seleção da obra para recebê-la em um tempo e lugar previamente determinados, assim como a inclusão em base de dados, o armazenamento em computador e outras formas de arquivamento dependem de autorização prévia e expressa do autor.

\footnotetext{
${ }^{54}$ A lei define reprodução como "a cópia de um ou vários exemplares de uma obra literária, artística ou científica ou de um fonograma, de qualquer forma tangível incluindo qualquer armazenamento permanente ou temporário por meios eletrônicos ou qualquer outro modo de fixação que venha a ser desenvolvido".

${ }^{55}$ A lei define distribuição como "a colocação à disposição do público do original ou cópia de obras literárias, artísticas ou científicas, interpretações ou execuções fixadas e fonogramas, mediante a venda, locação ou qualquer forma de transferência de propriedade ou posse".
} 
Já o direito autoral sobre atividades relativas a bases de dados é tratado em dois artigos.

O artigo 7, inciso XIII identifica as bases de dados como obras de criação intelectual. Em seguida, o mesmo artigo estabelece que:

"A proteção concedida no inciso XIII não abarca os dados ou materiais em si mesmos e se estende sem prejuízo de quaisquer direitos autorais que subsistam a respeito dos dados ou materiais contidos nas obras".

Neste caso específico, o que se entende é que o artigo protege as bases de dados, mas não os seus registros individualmente. No entanto, os registros em si também são passíveis de direito autoral, desde que assim requeiram seus detentores.

O artigo 87 concede ao titular do direito patrimonial da base de dados, 0 direito de autorizar ou proibir a reprodução total ou parcial por qualquer meio ou processo, tradução, adaptação, reordenação ou qualquer outra modificação, distribuição do original ou de cópias, e a reprodução, distribuição ou comunicação ao público do produto resultante de tradução, adaptação ou reordenação. (Brasil, 1998). 


\section{CONCLUSÃO}

Atividades de pesquisa e acesso a fontes de informação eletrônica estão se tornando cada dia mais complexas e interdependentes, tanto pela ação da tecnologia, quanto pelos efeitos das mudanças globais que incidem diretamente sobre os provedores de informação como agentes de mudanças para a sociedade da informação e do conhecimento.

Graças ao desenvolvimento da Tecnologia da Informação, hoje, a informação pode ser gerenciada de forma mais efetiva e transportada pelo mundo todo quase imediatamente, o que favorece o trabalho de muitos pesquisadores.

Mas vimos também que quando a informação não é bem gerenciada e não oferece sistematização metodológica adequada, esta pode até atrapalhar.

Assim sendo, o acesso a informações rápidas, precisas, confiáveis e relevantes são essenciais ao trabalho dos pesquisadores em qualquer área.

Quanto à pesquisa na área de Turismo, verificamos que sua natureza abrangente e multidisciplinar torna a busca por informações especializadas um tanto complicada, principalmente pela ausência de estratégias e metodologias aplicadas à área, dificultadas ainda pela pluralidade de temas e abordagens inerentes à área.

Portanto, a estratégia de busca sugerida neste trabalho visa amenizar esta dificuldade na recuperação da informação especializada em Turismo, de forma a diminuir a distância entre o pesquisador e a informação. 
Entretanto, a pesquisa e o acesso às fontes eletrônicas de informação são temas bastante amplos e inter-relacionados e o conhecimento produzido neste estudo, certamente, não esgota o assunto, de forma que pesquisas desta natureza devem ser complementadas por outras mais verticalizadas, que aprofundem questões mais específicas de disseminação, recuperação e acessibilidade informacional. 


\section{SUGESTÕES PARA ESTUDOS FUTUROS}

O escopo desenvolvido neste trabalho pode ser complementado e aperfeiçoado por outros estudos. Sugestões de outras pesquisas incluem:

Identificação e análises dos fatores que afetam, mais especificamente, a produção e a transferência da informação em Turismo, relacionadas aos usuários e pesquisadores brasileiros;

Desenvolvimento de aplicações de novos serviços eletrônicos em rede para o acesso à informação em Turismo;

$>$ Desenvolvimento de modelos organizacionais para o compartilhamento de serviços apropriados à realidade financeira, administrativa, tecnológica, social e cultural de bibliotecas ou unidades de informação especializadas em Turismo;

Análise de estudos de usuários relacionados ao uso das novas tecnologias da informação na área de Turismo. 


\section{GLOSSÁRIO}

\section{Acessibilidade}

A acessibilidade implica na quantidade de esforço e tempo necessários para encontrar uma fonte.

\section{Acesso}

"Possibilidade de consulta aos documentos de arquivos, as quais poderão variar em função de clausulas restritas". (ABNT, NBR 9578, 1986).

\section{Busca da informação}

São os caminhos seguidos pelos indivíduos para tentarem resolver as suas necessidades de informação. (CHEN, 1982).

\section{Biblioteca eletrônica ou digital}

Biblioteca cujos conteúdos estão em forma eletrônica e digital e são acessados localmente ou por meio de redes de comunicação.

\section{Biblioteca virtual}

Serviço que reúne informações antes dispersas, que são capturadas, organizadas, sistematizadas, integradas e disponibilizadas em rede. Consiste em dados e metadados relativos a documentos, pessoas, instituições, serviços e objetos, existentes nas mais diversas formas. As informações podem ser apresentadas mesclando texto e multimídia (imagem, som e vídeo).

\section{COMUT}

Serviço de comutação bibliográfica criado pelo IBICT. Disponível em: <http://www.ibict.br/comut/>

\section{Digital Subscriber Line - DSL}

Linha digital de assinante. Termo genérico que abrange todos os tipos de linhas digitais de assinantes, entre os quais ADSL e SDSL.

\section{Digitalização}

Conversão de qualquer tipo de informação para o formato digital. 
File Transfer Protocol - FTP

Protocolo usado para transferir arquivos entre computadores (Protocolo de transferência de arquivos).

\section{Fontes de Informação}

São todos os tipos de meios (suportes) que contém informações suscetíveis de serem comunicadas.

\section{FTP}

File Transfer Protocol (Protocolo de transferência de arquivos).

\section{Hipertexto}

Texto que contém links (apontadores, elos) para outros documentos ou outras partes do mesmo documento. Os elos estão associados a palavras ou expressões que permitem ao leitor se deslocar automaticamente para as partes por eles apontadas.

\section{Home page}

Principal e primeira página de um website. Serve como índice ou sumário de documentos armazenados naquele ou em outro site.

HPC

High Performance Computing (Computação de alto desempenho).

\section{HPCC}

High Performance Computing and Comunication (Computação e comunicação de alto desempenho).

HTML

Hypertext Markup Language (Linguagem de marcadores para hipertexto).

\section{HTTP}

Hypertext Transfer Protocol (Protocolo de transferência de hipertexto).

\section{Hypertext Markup Language - HTML}

Linguagem de marcação de hipertexto. Linguagem padrão usada para escrever páginas de documentos para WWW, variante (subconjunto) da SGML. Possibilita 
preparar documentos com gráficos e links, para visualização em sistemas compatíveis com o WWW.

\section{Hypertext Transfer Protocol - HTTP}

Protocolo de transferência de hipertexto. Conjunto de regras para intercâmbio de informações (texto, imagens, som, vídeo, e outros arquivos multimídia) na WWW. É um protocolo de aplicação.

\section{Infra-estrutura avançada}

Sistema de telecomunicações (hardware e software) que permite conexões digitais a longa distância, com qualidade de serviço e alta velocidade. As taxas de transmissão alcançadas por esse sistema devem estar adequadas ao atendimento das demandas, ou seja, devem ser suficientes para as diversas aplicações.

\section{Internet Protocol - IP}

Protocolo de Internet. Protocolo responsável pelo roteamento de pacotes entre dois sistemas que utilizam a família de protocolos TCP/IP usada na Internet. Protocolo básico da Internet.

\section{Internet}

Sistema mundial de redes de computadores - uma rede de redes - que pode ser utilizado por qualquer pessoa, em qualquer parte do mundo, onde haja ponto de acesso, e que oferece um amplo leque de serviços básicos, tais como correio eletrônico, acesso livre ou autorizado a informações em diversos formatos digitais, transferência de arquivos. Os protocolos básicos para o transporte dos dados são do TCP/IP.

\section{Link}

Elo ou apontador para outros documentos e/ou partes do documento, em hipertexto.

\section{Metadados}

Dados a respeito de outros dados, ou seja, qualquer dado usado para auxiliar na identificação, descrição e localização de informações. Trata-se, em outras palavras, de dados estruturados que descrevem as características de um recurso de informação.

\section{On-line}

Termo utilizado desde 1950, significa estar conectado a computadores ou sistemas de telecomunicações. "Em linha" é a tradução desse termo e possui 
variantes como online, on the line, OnLine, on line. O oposto é off-line, fora de linha, que não está ligado a um computador.

\section{Open Systems Interconnection - OSI}

Sistema aberto de interconexão. Modelo de referência do modo como, em uma rede de comunicações, as mensagens devem ser transmitidas, a partir da definição de sete camadas de funções existentes em cada ponta da comunicação. É adotado como padrão internacional pela ISO.

\section{Portal}

Site que reúne produtos e serviços de informação de determinada área de interesse e também de interesse geral. Portais de acesso à web normalmente oferecem, por exemplo, serviços gratuitos de correio eletrônico, notícias, chat, informações sobre o tempo, cotação de ações, facilidade para procurar outros sites, etc.

\section{Protocolo}

Conjunto de regras que formam uma linguagem utilizada pelos computadores para intercomunicação.

\section{Provedor}

Empresa ou instituição que presta serviços Internet.

\section{SDSL}

Symmetric Digital Subscriber Line (Linha de assinante digital simétrica).

\section{Servidor}

Programa que presta determinado serviço por demanda geralmente via rede. $\mathrm{Na}$ Internet, em particular, servidor de web é o programa que atende a solicitações de páginas ou arquivos em HTML.

\section{Site}

Coleção de páginas da web referentes a um assunto, instituição, empresa, pessoa etc. Diz-se também website. A forma portuguesa sítio é pouco usada.

\section{TCPIIP}

Transmission Control Protocol/Internet Protocol (Protocolo de controle de transmissão/Protocolo da Internet). 
Tecnologias de Informação e Comunicação

Tecnologias utilizadas para tratamento, organização e disseminação de informações. Pode-se utilizar a abreviação TIC.

Transmission Control Protocol/Internet Protocol - TCP/IP

Protocolo de controle de transmissão/Protocolo da Internet. Conjunto de protocolos básicos da Internet, que permitem a entrega de pacotes de um host para outro.

Uniforme Resource Locator - URL

Localizador de páginas da Internet. Forma padronizada de endereçar recursos na Internet.

URL

Uniforme Resource Locator . (Localizador de páginas da Internet)

World Wide Web - WWW

Teia global. Enorme conjunto de documentos e serviços, que faz parte da Internet, organizados em forma de páginas de hipertexto, em que cada página é dentificada por um URL. Também é chamada de web. 


\section{REFERÊNCIAS BIBLIOGRÁFICAS}

ACERENZA, Miguel Angel. Administracion del turismo: conceptualizacion y organizacion. 4. ed. México: Trillas, 1991. 2 v.

BENI, Mário Carlos. Análise estrutural do turismo. 8. ed. São Paulo: Senac, 2003. $523 \mathrm{p}$.

ALMEIDA JÚNIOR, O. F. de. Paradigmas e paradigmas : reflexões para ampliar a discussão. In: SIMPÓSIO BRASIL-SUL DE INFORMAÇÃO, 1996, Londrina. Anais... Londrina: UEL/Departamento de Biblioteconomia, 1996.

ANSARAH, Marília Gomes dos Reis. Formação e capacitação do profissional em turismo e hotelaria: reflexões e cadastro das instituições educacionais do Brasil. São Paulo: Aleph, 2002. p. 202.

ARAÚJO, E. A. de. Sociedade de informação: espaço onde o silêncio mora? São Paulo: Associação Paulista de Bibliotecários, 1996.

ARAÚJO, V. M. R. H. de. Sistemas de informação : nova abordagem teórico-conceitual. Ciência da Informação, Brasília, v. 24, n. 1, p. 54-76, jan./abr. 1995.

BARRETO, Auta Rojas. A informação eficaz na empresa. Ciência da Informação, Brasília, v. 20, n. 1, p. 78-81, jan./jun. 1991.

BATES, M. E. The making of a super searcher. Searcher, v. 7, n. 10, p. 33-35, 1999.

Where should the person stop and the information search interface start? Information Processing and Management, v. 26, n. 5, p. 575-591, 1990.

BAYMA, Maria de Fátima Castro. Enfoque de marketing na distribuição da revista $\mathrm{PAB}$, como produto de informação. Revista de Biblioteconomia de Brasília, Brasília, v. 22, n. 1, [200?] Disponível em: <http://rbb.org.br/V2324/N1/bayma.htm> Acesso em: 19 nov. 2005.

BELL, Daniel. O Advento da Sociedade Pós-Industrial. São Paulo: Ed. Cultrix, 1977.

BENI, Mario Carlos. Globalização do turismo: megatendências do setor e a realidade brasileira. 2. ed. São Paulo: Aleph, 2004. 208 p.

BLATTMANN, Úrsula. Modelo de gestão da informação digital on-line em bibliotecas acadêmicas na educação à distância: biblioteca virtual. 2001. Tese 
(Doutorado em Engenharia de Produção) - Programa de Pós-Graduação em Engenharia de Produção, Universidade Federal de Santa Catarina, Florianópolis, Disponível em: <http://teses.eps.ufcs.br/defesa/pdf/2916.pdf> Acesso em $11 \mathrm{dez}$. 2005.

BORGES, M. E. N. A informação como recurso gerencial das organizações na sociedade do conhecimento. Ciência da Informação, Brasília, v. 24, n. 2, p. 181188, maio/ago. 1995.

BUXTON, Andrew. Database searching : history, current and future developments. In: CONGRESSO REGIONAL DE INFORMAÇÃO EM CIÊNCIAS DA SAÚDE, São Paulo, outubro, 1992. 16p.

CAMPELLO, Bernadete Santos \& CAMPOS, Carlita Maria. Fontes de informação especializada características e utilização. 2.ed. Belo Horizonte : Editora UFMG, 1993. 159p.

CARDOSO, Ana Maria Pereira. Pós-modernidade e informação: conceitos complementares? Perspectivas em Ciência da Informação , Belo Horizonte, v. 1, n. 1, p. 63-79, jan./jul. 1996.

CASSIOLATO, J. E. e LASTRES, H. M. "Inovação, Globalização e as Novas Políticas de Desenvolvimento Industrial e Tecnológico". In: Globalização e Inovação Localizada: Experiências de Sistemas Locais no Mercosul, IBICT/IEL, Brasília, 1999.

CASTELLS, Manuel. A era da informação: economia, sociedade e cultura. 3. ed. São Paulo: Paz e Terra, 2002. 3v.

A galáxia da Internet: reflexões sobre a Internet, os negócios e a sociedade. Rio de janeiro: J. Zahar, 2003. . A sociedade em rede. 7. ed. São Paulo: Paz e Terra, 2003.

CASTRO, C. A., RIBEIRO, M. S. P. Sociedade da informação: dilema para o bibliotecário. Transinformação, Campinas, v. 9, n. 1, p. 17-25, jan./abr. 1997.

CENTENO, Rogelio Rocha. Metodologia da pesquisa aplicada ao turismo: casos práticos. São Paulo: Roca, 2003. 121 p.

CHARTIER, Roger. Do códice ao monitor : a trajetória do livro. Estudos Avançados, IEA/USP, v.8, n. 21, p.185-199, 1994

CHAUI, M. Convite à filosofia. 11. ed. São Paulo : Ática. 1999.

CHEN, C. C. Information seeking: assessing and anticipating user needs. New York: Neal; Schuman, 1982. 
CHEN, Chen-Tung; TAI, Wei-Shen. An information push-delivery suystem design for personal information service on the Internet. Information processing and management, v. 39, p. 873-888, 2003.

CHIZZOTTI, Antônio. Pesquisa em ciências humanas e sociais. São Paulo: Cortez, 1995.

CHOO, C. W. How we come to know: a general model of information use. In: . The knowing organization. New York: Oxford University Press, 1998.

CONSELHO NACIONAL DE CIÊNCIA E TECNOLOGIA (Brasil). Sociedade da informação : ciência e tecnologia para a construção da sociedade da informação no Brasil. Brasília, 1998.

COOPER, Chris. Educando os educadores em turismo: manual de educação em turismo e hospitalidade. Rio de janeiro: Roca, 2001. 202 p.

CRAWFORD, S. Information needs and uses. In: WILLIAN, M. E., Annual Review of Information Science and Technology. White Plains, Knowledge Industry, v.13, 1978.

CUNHA, Murilo Bastos da. As tecnologias de informação e a integração das bibliotecas brasileiras. In: SEMINÁRIO NACIONAL DE BIBLIOTECAS UNIVERSITÁRIAS, 8, Campinas, 7 a 11 de novembro de 1994. p.105-122.

- Metodologias para estudo dos usuários de informação científica e tecnológica. Revista de Biblioteconomia de Brasília, Brasília, v.10, n.2, p.5-19, jul./dez.1982.

Para saber mais: fontes de informação em ciência e tecnologia. Brasília: Briquet de Lemos/Livros, 2001.

CUNHA, Murilo Bastos da; ROBREDO, Jaime. Necessidade de integração das políticas de informação no Mercosul. Ciência da Informação, v.22, n.1, p.7-12, 1993.

DAVENPORT, Thomas H. Ecologia da informação: porque só a tecnologia não basta para o sucesso na era da informação. São Paulo: Futura, 2001.

DIAS, Reinaldo; AGUIAR, Marina Rodrigues de. Fundamentos do turismo: conceitos, normas e definições. Campinas: Alínea, 2002. 287 p.

DIZARD, Wilson P. A nova mídia: a comunicação de massa na era da informação. 2. ed. Rio de janeiro: Zahar, 2000. 324 p.

DRUCKER, Peter F. The coming of the new organization. Harvard Bussiness Review, jan./fev. 1988. 
ESCARPIT, R. Théorie générale de l'information et de la communication. Paris: Hachette, 1990.

FIGUEIREDO, Nice Menezes de. Metodologias para promoção do uso da informação: técnicas aplicadas particularmente em bibliotecas universitárias e especializadas. São Paulo:Nobel, 1991.

GASTAL, Susana. Turismo: 9 propostas para um saber-fazer. 3. ed. Porto Alegre: Edipucrs, 2002. 150 p.

GIDDENS, Anthony. As conseqüências da modernidade. 2. ed. São Paulo: Ed Unesp, 1991. $177 \mathrm{p}$.

GIDDENS, Anthony. Mundo em descontrole: o que a globalização está fazendo de nós. 4.ed. Rio de Janeiro: Record, 2005. 108 p.

GOELDNER, Charles R. Turismo: Princípios, práticas e filosofias. 8. ed. Porto Alegre: Bookman, 2002. 478 p.

HABERMAS, Jurgen. A modernidade: um projeto inacabado. Crítica, Lisboa, n. 2, p. 5-23. nov. 1987.

HARVEY, David. Condição pós-moderna: uma pesquisa sobre as origens da mudança cultural. 5. ed. São Paulo: Loyola, 1992. 349 p.

IANNI, Octavio. Globalização : novo paradigma das ciências sociais. Estudos Avançados, IEA/USP, v.8, n.21, p.147-163, 1994.

IGNARRA, Luiz Renato. Fundamentos do turismo. São Paulo: Pioneira, 2000. $135 p$.

LAGE, Beatriz Helena Gelas Milone, Paulo César. Turismo: teoria e prática. São Paulo: Atlas, 2000. 376 p.

LANCASTER, F. W. Indexação e resumos: teoria e prática. 2. ed. atual. Brasília: Briquet de Lemos, 2004. 452 p.

LE COADIC, Yves-François. A Ciência da Informação. Brasília: Briquet de Lemos, 2004.

LOJKINE, J. A revolução informacional. São Paulo: Cortez Editora, 1995.

LOPES, Ilza Leite. Search strategy in information retrieval: literature review. Ci. Inf., v. 31, n. 2, p.60-71, may/aug. 2002.

LUCAS, C. R. A organização do conhecimento e tecnologias da informação. Transinformação, Campinas, v. 8, n. 3, p. 59-65, set./dez. 1996. 
LYOTARD, Jean François. La condition post-moderne: rapport sur le savoir. Paris: Éd. de Minuit, 1979.

O pós-moderno. 3. ed. Rio de Janeiro: J.Olympio, 1988.125p.

MALIN, A. B. Economia e política de informação: novas visões da história. São Paulo em Perspectiva, v. 8, n.4, p. 9.18, out./dez. 1994.

MARCONDES, D. A crise de paradigma e o surgimento da modernidade. In: BRANDÃO, Z. (Org.). A crise dos paradigmas e a educação. São Paulo: Cortez, 1994. p. $16-29$.

MARENGO, L. A sociedade de informação e o mercado de trabalho. Transinformação, Campinas, v. 8, n. 1, p. 112-143, jan./abr.

1996.

MATIAS, Marlene. Turismo: formação e profissionalização (30 anos de história). Barueri: Manole, 2002. 106 p.

MEADOWS, Arthur Jack. A comunicação científica. Brasília: Briquet de Lemos, 1999. 268 p.

MENDES, Raquel Dias. Inteligência artificial: sistemas especialistas no gerenciamento da informação. Ci. Inf., v. 26, n.1, abr. 1997.

McGarry, Kevin. O contexto dinâmico da informação: uma análise introdutória. Tradução de: Helena Vilar de Lemos. Brasília: Briquet de Lemos, 1999. 206 p.

McGEE, James; PRUSAK, Laurence. Gerenciamento estratégico da informação: aumente a competitividade e a eficiência de sua empresa utilizando a informação como uma ferramenta estratégica. Rio de Janeiro: Campus, 1994.

McKAY, Donald. Information mechanism and meaning. Cambridge: Mit Press, 1969.

MCLUHAN, M. Understandig media: The Extensions of Man. Cambridge: MIT Press, 1996.

MOESCH, Marutschka Martini. A produção do saber turístico. 2. ed. São Paulo: Contexto, 2002.

MONTALLI, Katia Maria Lemos; CAMPELLO, Bernardete dos Santos. Fontes de informação sobre companhias e produtos industriais: uma revisão de literatura. Ci. Inf., v. 26, n. 3, set./dez. 1997.

MORAN, J. M. Interferências dos meios de comunicação no nosso conhecimento. Ciência da Informação, 1994. 
MORRIS, R. C. T. Toward a user-centered information science. Journal of the American Society for Information Science, v. 45, n.1, jan. 1994.

O'BRIEN, James A. Sistemas de informação e as decisões gerenciais na era da internet. 9. ed. São Paulo: Saraiva, 2001. 436 p.

O'CONNOR, Peter. Distribuição da informação eletrônica em turismo e hotelaria. Porto Alegre: Bookman, 2001. 171 p.

OJALA, M. The rhythm of searching. Online, v. 20, n. 4, p. 52-54, July/Aug. 1996.

PLASTINO, C. A. A crise dos paradigmas e a crise do conceito de paradigma. In: BRANDÃO, Z. (Org.). A crise dos paradigmas e a educação. São Paulo : Cortez, 1994. p. 32-47.

PEARCE, Douglas G; BUTLER, Richard W (orgs.) Desenvolvimento em turismo: temas contemporâneos. São Paulo: Contexto, 2002. 325 p.

RAMOS, Magda Camargo Lange. A utopia dos bits: impacto das tecnologias de informação na interação bibliotecário/usuário (graduação) da Biblioteca Universitária da Universidade Federal de Santa Catarina. 2003. Dissertação (Mestrado em Engenharia de Produção) - Programa de Pós-Graduação em Engenharia de Produção, Universidade Federal de Santa Catarina, Florianópolis, 2003.

REJOWSKI, Mirian. Turismo e pesquisa cientifica: pensamento internacional $\mathrm{x}$ situação brasileira. 7. ed. Campinas: Papirus, 2003.

SÁNCHEZ GAMBOA, S. Revolução informacional : pontos de vista para o debate sobre a sociedade da informação. Transinformação, Campinas, v. 9, n. 1, p. 32-42, jan./abr. 1997.

SANTOS, Boaventura de Sousa. Introdução a uma ciência pós-moderna. 3. ed. Rio de janeiro: Graal, 2000. 176 p.

SANTOS, Boaventura de Sousa. Um discurso sobre as ciências. 3. ed. São Paulo: Cortez, 2005. 92 p.

SANTOS, Jair Ferreira dos . O que é pós-moderno. 6. ed. São Paulo: Brasiliense, 1989. 111p.

SCOTTI, E. V. et al. O terceiro milênio e o paradigma da informação. Encontros Bibli:Revista de Biblioteconomia e Ciência da Informação, Florianópolis, n. 8, set.1999.Disponível em:< http://www.ced.ufsc.br/bibliote/encontro/bibli8/bibli8.html> 
SEVCENKO, Nicolau. O enigma pós-moderno. IN: OLIVEIRA, Roberto Cardoso et.al. Pós- modernidade. Campinas: Ed.Unicamp, 1987. p.43-55

SHANNON, Claude; WEAVER, Warren. A teoria matemática da comunicação. São Paulo: DIFEL, 1975.

SHAPIRO, Carl; VARIAN, Hal R. A economia da informação: como os princípios econômicos se aplicam à era da Internet. 4. ed. Rio de Janeiro: Campus, 1999. $397 \mathrm{p}$.

SHERA, Jesse. Epistemologia social, semântica geral e biblioteconomia. Ciência da Informação, v.6, n.1, p.9-12, 1977.

SHIGUNOV NETO, Alexandre; MACIEL, Lizete S. B. (orgs.). Currículo e formação profissional nos cursos de turismo. Campinas: Papirus, 2002. 206 p.

TÁLAMO, M. de F. G. M. Estabelecendo contato com o século XXI : visões do futuro informacional. In: SIMPÓSIO BRASILSUL DE INFORMAÇÃO, 1996, Londrina. Anais... Londrina : UEL/Departamento de Biblioteconomia, 1996. p. 201206.

TARAPANOFF, Kira. O profissional da informação na sociedade do conhecimento: oportunidades e desafios. In: Seminário Nacional de Bibliotecas Universitárias, 10., 1998, Fortaleza. [S.I. : s. n.], 1998.

- O profissional da informação pensando estrategicamente. In: Simpósio Brasil-Sul de Informação, 1996, Londrina. Anais. Londrina: UEL/Departamento de Biblioteconomia, 1996. p. 115-141.

TARGINO, M. das G. Novas tecnologias de comunicação: mitos, ritos ou ditos? Ciência da Informação, Brasília, v. 24, n. 2, p. 194-203, maio/ago. 1995.

TRIGO, Luiz Gonzaga Godoi; ANSARAH, Marilia Gomes dos Reis (orgs.). Turismo: como aprender, como ensinar. 3. ed. São Paulo: Senac, 2003. 2 v.

TRIGO, Luiz Gonzaga Godoi. Sociedade pós-industrial e o profissional em turismo. 5. ed. Campinas: Papirus, 2001. 248 p.

TRIGO, Luiz Gonzaga Godoi. Turismo e qualidade: tendências contemporâneas. 7. ed. Campinas: Papirus, 2001. 120 p.

WIENER, Norbert. The human use of human beings: cybernetics and society. Cambridge, Mass.: MIT Press, 1960.

YOUNG, Peter R. Changing information access economics: new roles for libraries and librarians. Information Technology and Libraries, p. 103-114, jun. 1994. 
YUAN, W. End-user searching behavior in information retrieval: a longitudinal study. JASIS, v. 48, n. 3, p. 218-234, Mar. 1997. 